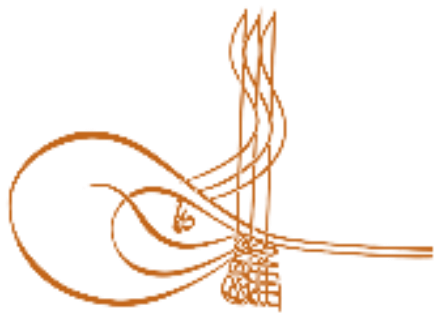

www.turkishstudies.net/social
Turkish Studies - Social Sciences

eISSN: $2667-5617$

Research Article / Araștırma Makalesi

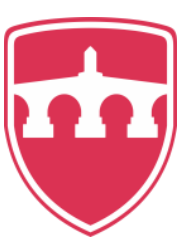

INTERNATIONAL

BALKAN

UNIVERSITY

Sponsored by IBU

\title{
Sosyal Medya Kullanımı ile Marka Farkındalığı ve Marka Sadakati Arasındaki İlişkinin İrdelenmesi*
}

\author{
Investigation of the Relationship Between Social Media Use and Brand Awareness and Brand \\ Loyalty
}

Yusuf Öcel $^{* *}$

\begin{abstract}
The main objective of this research is to examine the effects of social media usage on brand awareness and brand loyalty. The sub-objectives of the research are to identify the social media tools that the participants use the most, examine how much time they spend on social media on average per day, and analyze the purpose of using social media. The population of the research, which took into account the Nike and Adidas brand, is the people between the ages of 20 and 39 living in Duzce. Data is collected by convenience sampling. Data were collected from 291 people by face-to-face survey method. Frequency, factor, correlation, and regression analyses were applied to the data obtained. As a result of factor analysis are emerged three factors related to social media use (social motivation, psychological motivation and functional motivation), two factors related to brand awareness (brand recognition and brand recall), and two factors related to brand loyalty (attitude loyalty and behavioral loyalty). According to the results of the correlation analysis, when the two brands are compared, it is seen that the brand recognition for the Nike and the brand recall for the Adidas is emerged in the relationship between social media usage and brand awareness. In brand loyalty, it is seen that comes to the forefront of behavioral loyalty for the Nike and attitudinal loyalty for Adidas. According to the results of regression analysis, it is concluded that social motivation and psychological motivation are an effect on brand awareness and brand loyalty in both brands.
\end{abstract}

Structured Abstract: In this study, the effect of social media usage on brand awareness and brand loyalty is examined by considering the perceptions of consumers related to Nike and Adidas brand. With each passing day, companies strive to reveal brand differences and to place brand awareness in the minds of consumers. In the researches, it is observed that consumers who are familiar with brands are in purchasing behavior (Aaker, 1996: 25). The use of the internet, which started in the 1970s and continued rapidly after the 1990s, increased the number of users with the spread of web sites and portals, and reached the points of interest to people from all walks of life through the intensive use of social media in the 2000s (Vural \& Bat, 2010: 3349). In this study,

\footnotetext{
* Bu çalışma 10. Sosyal Bilimlerde Güncel Tartışmalar Uluslararası Kongresinde (CUDES) sözlü bildiri olarak sunulmuştur.

*** Dr. Öğr. Üyesi, Düzce Üniversitesi, İşletme Fakültesi, İşletme Bölümü

Asst. Prof. Dr., Duzce University, Faculty of Business Administration, Department of Business

ORCID 0000-0002-4555-7035

yusufocel@duzce.edu.tr

Cite as/ Atıf: Öcel, Y. (2020). Sosyal medya kullanımı ile marka farkındalığı ve marka sadakati arasındaki ilişkinin irdelenmesi, Turkish Studies - Social, 15(2), 257-279. https://dx.doi.org/10.29228/TurkishStudies.40027

Received/Geliş: 05 December/Aralık 2019

Accepted/Kabul: 25 February/Şubat 2020

Checked by plagiarism software

Copyright $(C)$ INTAC LTD, Turkey

Published/Yayın: 29 February/Şubat 2020

CC BY-NC 4.0
} 
the brand awareness and which brand should be addressed in sports clothing brands are emphasized. Perceptions of the participants were measured which is considering Nike and Adidas brands. According to the research conducted by Brandwatch social media observation company, Nike $(788,490)$, which is the second most visible brand in social media, and Adidas brand (772,520) is the third (Richter, 2018). It is also taken into consideration that these brands carry out various communication activities on social media. It is also thought that these two brands will be able to compete with each other.

According to the results of Turkey Statistical Institute had done in the month of April 2017 "Household ICT Usage Survey", 80.7\% of households have Internet access. Digital marketing agency We Are Social, Hootsuite prepared in collaboration with the "Digital in 2017 Global Overview" report, 48 million of Turkey's population is observed that the active use of social media. In this case, the increasing use of the internet and social media has not been overlooked by the enterprises. In this way, businesses use the internet and social media effectively as a tool for creating brand awareness and aim to reach customers faster. Thanks to social media, it is easier for businesses to reach consumers and fewer budgets can be allocated to create brand awareness compared to traditional ways. In this context, the research results are commercially important.

The universe consists of people between the ages of 20 and 39 who live in Duzce. It is assumed that this age group uses both social media and sportswear products more. According to the research conducted by We are social research company, it is seen that people between the ages of 20-39 are among the age groups that use social media the most. Quantitative method is used as data collection method and questionnaire is used as data collection technique. The field survey was conducted between 01.05.2019 and 15.06.2019. In this study, sampling method was convenience sampling. Data were collected from 291 people by face-to-face survey method. Social, psychological and functional motivation expressions and brand awareness expressions in the scale were taken from Topal and Temizkan's (2016) study. Expressions regarding brand loyalty were taken from the scale developed by Lau and Lee (1999) and translated into Turkish by Eren and Erge (2012). SPSS packet program was used for statistical analysis of the data obtained from the research.

When the research results are analyzed, the most commonly used social media tools are YouTube, Facebook, and Instagram respectively. According to the results of the participants' use of social media, respectively friendship and entertainment, shopping and fashion were the highest. Average on Social Media is spent between 1 and 4 hours per day. Participants spend an average of 1 to 4 hours per day on Social Media.

Considering the Nike brand, there are medium-level positive relationships between social motivation and brand recognition, a high-level of behavioral loyalty, and a low-level of attitude loyalty. There is a moderate-level positive relationship between psychological motivation and brand recognition, a low-level of brand recall, a moderate-level of behavioral loyalty and a low-level of positive correlation between attitudes. There is a moderate-level positive relationship between functional motivation, and brand recognition and behavioral loyalty. Accordingly, it is understood that there is more correlation between social media usage and brand recognition, and behavioral loyalty. Considering the Adidas brand, there are high positive relationships between social motivation and brand recall, a high level of attributional loyalty, and a low level of behavioral loyalty. There is a low level positive relationship between psychological motivation and brand recognition, medium-level between brand recall, medium-level between attitude loyalty and low level between behavioral loyalty. There are medium-level positive relationships between functional motivation and brand recall and attitudinal loyalty. In this respect, it is understood that there is more correlation between the use of social media and brand recall and attitude loyalty. When both brands are compared, In the brand awareness of the use of social media, recognition for the Nike brand and recall for the Adidas brand appear to be at the forefront. In brand loyalty, it is seen that behavioral loyalty comes to the forefront of the Nike brand and attitude loyalty for Adidas.

According to the results of the regression analysis considering the Nike brand, the relative importance of social media usage sub-dimensions on brand recognition is as follows; "Social motivation, psychological motivation and functional motivation". When t-test results related to the significance of regression coefficients are examined, it is seen that social motivation has a significant effect on brand recognition. In light of these findings; $\mathrm{H}_{1 \mathrm{a}}$ was accepted. It is seen that psychological motivation has a significant effect on brand recall. In light of these findings; $\mathrm{H}_{1 \mathrm{~h}}$ was accepted. It is seen that social motivation has a significant effect on behavioral loyalty. In light of these findings; $\mathrm{H}_{2 \mathrm{a}}$ was accepted. it was seen that psychological motivation had a significant effect on the attitude loyalty. In light of these findings; $\mathrm{H}_{2 \mathrm{~h}}$ was accepted.

Turkish Studies - Social, 15(2) 
According to the results of the regression analysis considering the Adidas brand, the relative importance of social media usage sub-dimensions on brand recall is as follows; "Social motivation, psychological motivation, and functional motivation". When t-test results related to the significance of regression coefficients were examined, it was seen that social motivation had a significant effect on brand recall. In light of these findings; $\mathrm{H}_{1 \mathrm{j}}$ was accepted. It is seen that psychological motivation has a significant effect on brand recognition. In light of these findings; $\mathrm{H}_{1 \mathrm{e}}$ was accepted. It is seen that psychological motivation has a significant effect on behavioral loyalty. In light of these findings; $\mathrm{H}_{2 \mathrm{e}}$ was accepted. It is seen that social motivation has a significant effect on attitudes. In light of these findings; $\mathrm{H}_{2 \mathrm{j}}$ was accepted.

Keywords: Marketing, consumer behaviour, social media, brand awareness, brand loyalty.

Öz: Bu çalışmanın temel amacı sosyal medya kullanımının marka farkındalığı ve marka sadakati üzerindeki etkilerini incelemektir. Araştırmanın alt amaçları ise katılımcıların en fazla kullandıkları sosyal medya araçlarını tespit etmek, sosyal medya da günde ortalama ne kadar zaman geçirdiklerini incelemek ve sosyal medyayı hangi amaçla kullandıklarını analiz etmektir. Nike ve Adidas markası dikkate alınarak yapılan araştırmanın evrenini Düzce ilinde yaşayan 20-39 yaşları arasındaki kişiler oluşturmaktadır. Yapılan bu çalışmada kolayda örneklem yöntemi seçilmiştir. Yüz yüze anket metodu ile 291 kişiden veriler toplanmıştır. Elde edilen verilere frekans, faktör, korelasyon ve regresyon analizleri uygulanmıştır. Yapılan faktör analizleri sonucunda sosyal medya kullanımı ile ilgili üç faktör (sosyal motivasyon, psikolojik motivasyon ve fonksiyonel motivasyon), marka farkındalığı ile ilgili iki faktör (marka tanınırlığı ve marka hatırlanırlığı), marka sadakati ile ilgili iki faktör (tutumsal sadakat ve davranışsal sadakat) ortaya çıkmıştır. Korelasyon analizi sonuçlarına göre her iki marka karşılaştırıldığında sosyal medya kullanımı ile marka farkındalığı arasındaki ilişkide Nike markası için marka tanınırlığının, Adidas markası için marka hatırlanırlığının ön plana çıktığı görülmektedir. Marka sadakatinde ise Nike markası için davranışsal sadakatin, Adidas markası için tutumsal sadakatin ön plana çıktığı görülmektedir. Regresyon analizi sonuçlarına göre her iki markada da sosyal motivasyonun ve psikolojik motivasyonun marka farkındalı̆̆ 1 ve marka sadakati üzerinde etkilerinin olduğu sonucuna ulaşılmıştır.

Anahtar Kelimeler: Pazarlama, tüketici davranışı, sosyal medya kullanımı, marka farkındalığı, marka sadakati.

\section{Giriș}

Günümüzde iletişim teknolojisi hızla değişmekte ve gelişmektedir. Kişilerde bu değişime uyum sağlamaktadır. Dolayısıyla hızla değişen iletişim teknolojileri karşısında işletmelerin ve insanların duyarsız kalması pek mümkün olmamaktadır. Devamlı gelişen iletişim teknolojileri beraberinde de tüketicilerin satın alma davranışlarını etkilemektedir. İşletmeler de bu değişimle birlikte müşterileriyle olan ilişkilerinde iletişim araçlarında yeniliklere başvurmaktadır. Artık geleneksel iletişim yöntemleri müşteriye ulaşmada yeterli görülmemektedir.

Günümüzde yeni medya kavramı yeni iletişim ortamları olarak tanımlanmaktadır. Yeni medya kavramı 1970'ler de bilgi ve iletişim tabanlı araştırmalarda, sosyal, psikolojik, ekonomik, politik ve kültürel çalışmalar yapan araştırmacılar tarafından ortaya atılmış bir kavramdır. Yeni medya kavramına 1970'lerde değinilen anlam, 1990'larda müthiş bir ivme kazanan bilgisayar ve internet teknolojisi ile birlikte genişlemiş ve farklı boyutlara ulaşmıştır (Dilmen, 2007: 114). 1970'lerde başlayan ve 1990'lardan sonra hızla devam eden internet kullanımı, 2000'li yıllarda sosyal medyanın işlerlik kazanmasıyla her kesimden insanı ilgilendirecek noktalara ulaşmış ve kullanıcı sayısını arttırmıştır (Vural ve Bat, 2010:3349). Tüketiciler çeşitli mobil cihazlarla (tablet, akı1lı telefon, bilgisayar) rahatlıkla internete bağlanabilmektedir. $\mathrm{Bu}$ doğrultuda tüketiciler ihtiyaçlarını gidermek için özel olarak tasarlanmış uygulamalardan ya da sitelerden alışverişlerini gerçekleştirebilmektedir. 2017 Nisan ayı içerisinde Türkiye İstatistik Kurumu'nun yapmış olduğu araştırma (Hane Halkı Bilişim Teknolojileri Kullanımı) sonuçlarına göre hanelerin \%80,7'si internete erişim imkânına sahiptir. Bunun anlamı her on hanenin sekizinin internete sahip olduğu gerçeğidir. İnternete sahip olanların internet üzerinden yaptıklanı alışveriş (16-74 yaş arası) oranı ise 
\%24,9'dur. Bu oran 2017 y1lı verilerine göre \%20,9'dur (TÜIK, 2017). Bu nedenle işletmelerin müşterilerine ulaşabilmesi için sosyal medya kanalları, internet ve sanal ortamları en iyi ve aktif şekilde kullanması gerekmektedir.

İnternetle birlikte günlük yaşamımızın vazgeçilmez parçalarından biri de sosyal medyadır. Sosyal medya, kullanıcılar tarafindan meydana getirilen bilginin çift taraflı, basit ve anlık olarak paylaşılmasını sağlayan yeni bir medya biçimidir. Dünya üzerinde 500'ü aşkın sosyal medya aracı bulunmaktadır. Yine Dünya üzerinde 3 milyar civarında kişi sosyal medya kullanmaktadır. Sosyal medyayı tüketiciler farklı amaçlar için kullanmaktadır. Eğlence, eğitim, arkadaşlık kurma, gündemi takip etme, film izleme vb. amaçlar için kullanılabilen sosyal medyanın gün geçtikçe kullanım alanı ve amacı da artmaktadır. Dijital pazarlama ajansı We Are Social, Hootsuite işbirliği ile hazırladığı "Digital in 2017 Global Overview" raporunda Türkiye nüfusunun 48 milyonunun aktif olarak sosyal medyayı kullandığı görülmektir. Türkiye'de en çok kullanılan sosyal medya platformlarına bakıldığında ise ilk sırada \%57 ile Youtube, \%56 ile Facebook ve \%45 ile Instagramdır (Wearesocial, 2018). İnternet ve sosyal medya kullanımının gün geçtikçe artış göstermesi işletmelerinde daha çok dikkatini çekmektedir. Özellikle mobil cihazlarda internet erişimi ile birlikte sosyal medya daha aktif bir şekilde kullanılmaktadır. Bu durumda sosyal medya işletmeler için, müşteriler ve stratejik ortakları etkilemek amacıyla kullanılan bir iletişim aracı hali almaktadır.

Her geçen gün gelişen pazarlama anlayışını benimseyen işletmeler marka farlılıklarını ortaya koymaya ve marka farkındalıklarının tüketici zihninde yer etmesine gayret etmektedir. Yapılan araştırmalarda markalara aşina olan tüketicilerin satın alma davranışında bulundukları gözlemlenmektedir (Aaker, 1996: 25). Bu durumda internet ve sosyal medya kullanımının giderek artması, değişime ayak uyduran işletmelerin gözünden kaçmamıştır. Böylelikle işletmeler internet ve sosyal medyayı marka farkındalığı oluşturmak için bir araç olarak etkin şekilde kullanıp müşterilere daha hızlı ulaşmayı amaçlamaktadır. Sosyal medya sayesinde işletmelerin tüketicilere ulaşması kolaylaşmakta, geleneksel yollara göre marka farkındalığı oluşturmada daha az bütçe ayrilabilmektedir.

Yeni müşteri elde etmenin mevcut müşterileri elde tutmaktan daha maliyetli olduğu (Kaynar ve diğ., 2017: 1) günümüz dünyasında müşteri sadakati kavramı da önem arz etmektedir. Bu doğrultuda sosyal medya ile birlikte marka sadakati oluşturup müşterileri elde tutmak üzerine çalışmalar yapılmaktadır. Bu çalışmada Nike ve Adidas markası ile ilgili tüketicilerin algıları dikkate alınarak sosyal medya kullanımının marka farkındalığı ve marka sadakati oluşturmada etkisi incelenmektedir. Nike ve Adidas markasının seçilmesinin ana nedeni sosyal medya da en çok görünen ve iletişim çalışması yapan markalar arasında bu markaların yer almasıdır (Richter, 2018). Özellikle mobil cihazlarla internete erişim, fotoğraf çekme, hızlı yorum yapabilme, gelişmeleri takip etme özellikleri ile sosyal medyanın içerisinde bulunan tüketicilerin işletmeler tarafindan daha fazla iletişim çalışmalarına maruz kalacağı düşünülmektedir. Bu durumda marka farkındalığı oluşumu olumlu yönde gelişeceği varsayılmaktadır.

\section{Sosyal medya kullanımı}

Sosyal medya, birbirine benzer ilgi alanlarına sahip kişilerin bir araya geldiği, paylaşım yapıldığı ve meydana getirilen gruplarla iletişim kurulduğu web sitelerine denilmektedir (Vural ve Bat, 2010: 3348). Web 2.0 iletişim teknolojisi ile hayatımıza giren sosyal medya da insanlar düşüncelerini paylaşabilmekte, içerik ekleyebilmekte ve yorum yapabilmektedir (Murugesan, 2007: 34). Sosyal medya dünyada çok hızlı bir şekilde yayılan sanal topluluk üyelikleri ile 1990'lı yılların sonlarında kendini hissettirmeya başlamıştır. İlk görülen sosyal medya siteleri classmates.com, sixdegress.com, asianavenue olarak bilinmektedir (Iovino, 2011: 16). Şu günlerde 500 civarında sosyal medya uygulaması içerisinde en popüler olanları Facebook, Youtube, Myspace, Twitter, Instagram, Linkedin gibi ağlardır (Wearesocial, 2019). Bu sosyal ağlar insanların artık yaşamlarının bir parçası haline gelmiştir.

Turkish Studies - Social, 15(2) 
Sosyal medya araçlarının kullanımı da birbirinden farklılaşmaktadır. Youtube insanların videolarını paylaştıkları, Facebook ve Myspace resim, video, kişisel bilgilerin paylaşıldığı, Twitter politikaya yönelik gündemin oluşturulduğu, Linkedin benzer mesleki alana sahip kişilerin bir araya geldiği sosyal medya araçlarıdır (Gümüş ve Zengin, 2018: 12-32).

İnsanları sosyal medya içeriği üretmeye sevk eden sebepler incelendiğinde sosyal, psikolojik ve fonksiyonel güdülerin etkili olduğu görülmektedir (Daugherty ve diğ., 2008). Yapılan araştırmalarda sosyal medya kullanımında bu faktörlerin etkileri araştırılmıştır. Bu araştırmalardan bazıları aşağıda açıklanmaktadır.

Mobil sosyal medya kullanımının marka farkındalığı üzerindeki etkilerini inceleyen bir araştırmaya göre sosyal motivasyon unsuru başta olmak üzere psikolojik ve fonksiyonel motivasyonun marka farkındalığı üzerinde etkilerinin olduğu ortaya çıkmıştır. Ayrıca sosyal medya araçlarından Facebook kullanıcılarının günde 1 saatten daha fazla zaman (\%90) geçirdiği belirtilmektedir. Aynı araştırma da korelasyon analizi sonuçlarına göre ise sosyal motivasyon ile marka farkındalığı arasında zayıf bir ilişki varken; fonksiyonel motivasyon ile marka farkındalığı arasında orta düzeyde bir ilişki bulunmuştur. Psikolojik motivasyon ile marka farkındalığı arasında ise anlamlı ilişki bulunmamıştır. Tüketicileri sosyal medya kullanımına iten en büyük güdüleyicinin sosyal motivasyon olduğu, daha sonra ise fonksiyonel motivasyonun olduğu ortaya çımıştır (Topal ve Temizkan, 2016: 1456-1465).

Sosyal medya kullanım amacını ortaya çıkarmak için 345 öğrenci üzerine yapılan bir araştırmada ise \%70'i sosyal medyayı boş zaman eğlencesi, \%47'si sosyalleşme aracı, \%29,6's1 alternatif yaşam, $\% 28$ 'i vakit geçirme, $\% 23,8$ 'ü özgürlük, $\% 15,7$ 'i sadece bir oyun, $\% 7,2$ 'si düşleri gerçekleştirme olarak algılamaktadır. Ayrıca öğrencilerin \%69.8'i günde 1 ile 5 saat arasında sosyal medyayı kullandıklarını belirtmişlerdir. (Vural ve diğ., 2016: 669).

2012 yılında yapılan başka bir araştırmada da insanların yine günde 1 saatten daha fazla zaman geçirdikleri (\%49.6) ve en fazla sosyal ağların \%91 (Facebook, Google Plus) kullanıldığı ortaya çıkmıştır. Ayrıca herhangi bir ürün almadan önce sosyal medyadan araştırma yapıldığı da belirtilmektedir (İşlek, 2012: 114-123).

\section{Marka farkındalığı}

Marka kavramı, herhangi bir işletmenin ürününü kendi ürünlerinden veya rakiplerin ürünlerinden ayırt etmeye yarayan, yeni ürünün kolayca pazarda bilinmesini sağlayan, yasal olarak ürünü koruyan, tüketicilere duygusal veya işlevsel vaatler sunan bir isim, sembol, resim, işaret, terim gibi kimlik unsurlarıdır (Aktuğlu, 2014).

Marka farkındalığı kavramı ise bir markanın adının, logosunun, ambalajının, karakterinin, sunduğu faydaların, biçimsel ve içeriksel işlevlerin kategori gereksinimi ile birleşimine denir (Tosun, 2014:131). Literatürde bazı kaynaklarda bu kavram marka bilinirliği olarak da incelenmektedir. Farkındalık ile bir markanın, tüketicinin satın alma sürecinde akla gelip gelmeyeceğini ve böylelikle tüketicinin markalar arasında o markayı da hesaba katıp katmayacağ ile ilgilidir (Aaker, 1996: 21). Keller'e göre marka farkındalığının üç önemli avantajı vardır. Bunlar marka imajına katkı, marka sadakatinin sağlanması ve diğer markalar arasından kolayca seçimdir (Keller, 2013: 46).

Marka farkındalığı içerisinde iki önemli alt kavram bulunmaktadır. Bunlar tanınırlık ve hatırlanırlıktır. Tanınırlık eski deneyimlerden oluşan aşinalığ 1 yansıtırken, hatırlanırlık ise bir ürün kategorsiniden bahsedildiği zaman veya ortaya çıkan bir ihtiyaç karşısında tüketicinin aklına markanın gelmesidir (Aaker, 1996: 24-25). Örneğin spor ayakkabıya ihtiyaç duyulduğu zaman Nike veya Adidas markasının tüketicinin aklına gelmesi hatılama iken, Nike veya Adidas'ın logosunun görüldügü yerde bu markaların olduğunun tüketici tarafindan bilinmesi tanımadır. Tanıma genel olarak görme, işitme veya dokunma gibi beş duyu organı ile hissedildikten sonra fark edilirken, 
hatırlama görmeden, işitmeden veya dokunmadan önce ortaya çıkan bir durumdur. Bir ihtiyaç oluştuğunda tüketicinin markayı hatırlaması, markadan bahsedildiğinde markanın ne işe yaradığının bilinmesinden daha önemlidir. Literatürde marka farkındalığı ile sosyal medya kullanımı arasındaki ilişkileri incelemeye yönelik çeşitli araştırmalar bulunmaktadır. Bu araştırmalardan bazıları aşağıda verilmektedir.

Sosyal medya aracı olarak facebook uygulamalarının marka farkındalığı üzerindeki etkisini incelemek üzere yapılan bir araştırma sonucuna göre marka farkındalığını sosyal medya üzerinde yapılan müşteri ilişkileri çalışmalarının en fazla etkilediği sonucuna ulaşılmıştır (Gümüş ve diğ., 2013: 112).

Yapılan başka bir araştırma da ise facebook sayfası ile etkileşimin marka bilinirliği, ağızdan ağıza iletişim ve satın alma niyeti üzerinde etkili olduğu sonucuna varılmıştır (Hutter ve diğ., 2013: $342)$.

Yapılan başka bir çalışma da ise marka farkındalığı oluşturmak için sosyal medyada etkileşimin, ödüllendirmenin, bilgi ve sistem kalitesinin iyi olmasının etkili olduğu sonucuna ulaşılmıştır. Ayrıca bu durumun ağızdan ağıza iletişimi de etkilediği sonucuna ulaşılmıştır (Barreda, 2015: 600).

Marka farkındalığ 1 oluşturmada dijital pazarlama iletişimi araçlarının etki seviyelerinin değerlendirilmesi konulu çalışma sonuçlarına göre marka bilinirliği oluşturmada kurumsal dijital iletişim araçlarının etkisinin (kurumsal web siteleri, arama motoru eklemeleri ve e-posta iletişimi vb.) sosyal medya araçlarından (Facebook, Twitter, Instagram vb.) daha yüksek olduğudur. Sosyal medya araçları içerisinde ise Facebook'un en etkili araç olduğu sonucunada varılmıştır. (Çizmeci ve Ercan, 2015: 159-160).

1243 kişi üzerinde gerçekleştirilen bir sosyal medya araştırmasında katılımcılar markalarla ilgili içerikler ve yorumların o markaya bakış açısında değişiklik yarattığını ifade etmişlerdir. Ayrıca Doritos ve Eti markaları üzerine yapılan aynı çalışma sonucuna göre tüketicilerin sosyal medyada bu markaların görülmesi ile bilgi toplamaları, web sitesini incelemeleri, mağazayı ziyaret etme, markaya karşı yaklaşımlarının olumlu yönde değişebilmesi, marka hakkında sosyal medyada paylaşım yapma, sosyal medya uygulamalarına katılabilmeleri yönünde anlamlı farklılıkların ortaya çıktığı görülmüş̧ür. Ayrıca çalışmada Doritos markası ile sosyal medyada karşılaşanların Eti markası ile karşılaşanlara göre göre daha fazla satın alma eylemine katılabileceklerini belirtmişlerdir (Vural ve diğ., 2016: 667-672).

Apple ve Samsung markalı ürünlerin tercih edilmesinde sosyal medyanın rolü üzerine yapılan bir çalışmada Samsung markasını tercih eden kullanıcıların, Apple markasını tercih eden kullanıcılara göre sosyal medya üzerinden indirim ve kampanyalar ile kullanım kolaylığından daha fazla etkilenmektedir. Apple markasını tercih eden kullanıcılar ise Samsung markasını tercih eden kullanıcılara göre sosyal medya üzerinde sorun çözülme durumuna, sosyal medyada yer alan olumlu reklamlara ve sosyal medyada yer alan bilgiler sonucu memnun olacaklarına göre daha fazla etkilendiği ortaya çıkmıştır (Yıldız, 2014: 12).

\section{Müşteri sadakati}

Müşteri sadakati kavramı bir ürün veya hizmeti satın alma sürekliliği ile bir ürün veya hizmet hakkında olumlu tutuma sahip olma durumları olarak açılanabilir. Davranışsal ve tutumsal sadakat olarak litertürde yer alan bu iki kavram müşteri sadakatinin alt yapısını oluşturmaktadır. Davranışsal sadakat kavramı müşteri sadakatini satış yüzdesine göre ele alırken; tutumsal sadakat kavramı müşteri sadakatini duygusal duruma göre ele almaktadırlar (Kim ve dĭg., 2007: 823; Dick ve Basu, 1994: 99; Zeithaml ve diğ., 1996: 34). Yani davranışsal sadakat ile bir ürünün müşteri tarafından satın alma tekrarı beklenirken, tutumsal sadakat ile bir işletme veya ürün hakkında müşterinin olumlu duygu ve düşüncelere sahip olması beklenmektedir (Çatı ve Koçoğlu, 2008: 169). 
GSM operatörü Turkcell markası dikkate alınarak yapılan bir çalışmaya göre sosyal medya iletişimi ile marka sadakati arasında pozitif ilişkinin olduğu ortaya çıkmıştır (Çakırkaya ve Koçyiğit, 2019: 2035). Türkiye Spor Toto Futbol kulüpleri üzerine yapılan çalışmada da (Fenerbahçe, Beşiktaş ve Galatasaray) sosyal medya aracılığı ile marka sadakati oluştuğu sonucuna varılmıştır (Karakuş, 2015). Moda giyim ürünleri üzerine yapılan bir çalışmada ise tüketicilerin sosyal medya ilgileniminin satın alma niyetini pozitif yönde etkilediği ortaya çıkmıştır (Yıldırım ve Boztepe, 2019: 340). Yapılan başka bir çalışmada sosyal medya algısının satın alma eğilimini, marka prestijini ve marka kredibiletisini (marka bilgilerinin inandırıcılığını) etkilediği sonucuna ulaşılmıştır (Kazancı ve Başgöze, 2015: 449-450).

Yapılan başka bir çalışma da sosyal medya da marka toplulukları oluşturmanın tüeticilerin marka, diğer tüketiciler, şirket ve ürünlerle ilişkilerini geliştirerek marka güvenini ve bağlllığını artırabileceği sonucuna ulaşılmıştır (Laroche ve diğ., 2013: 80).

Y kuşağının sosyal medya araçlarını kullanmasının marka sadakati ve satın alma niyeti üzerine etkisinin incelendiği başka bir çalışmada ise e-ağızdan ağıza iletişim çalışmalarının, çevrimiçi etkileşimlerin, çevrimiçi iletişim çalışmalarının marka bağlılığını ve ürün satın alma niyetini geliştirmede etkili olduğu sonucuna ulaşılmıştır (Balakrishnan ve diğ., 2014: 177).

Otel müşterileri üzerine yapılan bir araştırmada sosyal medya pazarlamasının marka bağl1lığ 1 üzerine etkisinin olup olmadığ 1 incelenmiştir. Araştırma sonuçlarına göre bağl1lık ve sosyal medya pazarlaması arasında bir ilişkinin olmadığı ortaya çıkmıştır. Bu durumun temel nedeni ise otel müşterilerinin daha çok seyehat acentelerinin iletişim araçlarını kullanmaları ile ilgili durumun olmasıdır (Tatar ve Erdoğmuş, 2016: 258).

Sosyal medya pazarlamasının marka bağlllı̆̆ ile ilişkisinin irdelendiği bir çalışma da işletmelerin sosyal medyada avantajlı kampanyalar, uygun/alakalı içerikler, popüler içerikler, çeşitli uygulamalar sunduğunda ve çeşitli platformlarda göründüğünde marka bağl1lığının oluştuğu sonucuna ulaşılmıştır (Erdoğmuş ve Çiçek, 2012: 1353).

İçecekler, giyim ve iletişim sektörlerinde faaliyet gösteren 60 marka üzerine yapılan sosyal medya iletişiminin tüketicilerin markaları algılamaları üzerine etkisi konulu araştırma sonuçlarına göre işletmenin oluşturduğu marka iletişimi çalışmalarının marka tutumunu etkilediği görülmüştür. Ayrıca kullanıcılar tarafından oluşturulan sosyal medya içeriklerinin ise marka denkliği ve marka tutumunu etkilediği sonucuna ulaşı1mıştır (Schivinski ve Dabrowski, 2016: 189).

Otel işletmeleri üzerine yapılan bir çalışma sonucuna göre ise hazcı, fonksiyonel ve güven faydalarının e-sadakat üzerine etkisi olduğu görülmüștür. Sosyal faydanın ise etkisinin olmadığı sonucuna ulaş1lmıştır (Ercan, 2016: 119).

\section{Araştırmanın Yöntemi, Hipotezleri, Evreni ve Örneklemi}

$\mathrm{Bu}$ araştırmanın temel amacı sosyal medya kullanımı ile marka farkındalı̆̆ı ve marka sadakati arasındaki ilişkinin olup olmadığının irdelenmesidir. Araştırmanın temel problemi marka farkındalığı ve marka sadakati oluşumunda sosyal medya kullanımının etkisinin ne düzeyde olduğudur. Araştırmada veri toplama tekniği olarak anket kullanılmıştır. Demografik özellikleri belirlemek için kategorik ölçek kullanılmıştır. Sosyal medya, marka farkındalığı ve marka sadakati değişkenleri için beşli likert ölçeği kullanılmış̧ır (1-kesinlikle katılmıyorum, 2-katılmıyorum, 3-orta düzeyde katılıyorum, 4-katılıyorum, 5-kesinlikle katılıyorum). Ölçekte yer Sosyal medya kullanımı ve marka farkındalığı ifadeleri Topal ve Temizkan'ın (2016) çalışmasından alınmıştır. Marka sadakati ile ilgili ifadeler ise Eren ve Erge (2012) tarafından Türkçeye çevrilen Lau ve Lee (1999) tarafından geliştirilen ölçek kullanılmıştır. Marka farkındalı̆̆g ile ilgili ölçekte ise Aaker'in (1996) çalısmasından faydalanılmıştır. İstatistiksel analizinin yapılmasında ise SPSS programı kullanılmıştır. 
Literatür araştırması ile desteklenerek hazırlanan araştırma modeli (Şekil-1); sosyal medya kullanımı, marka farkındalığı ve marka sadakati olmak üzere üç temel değişkenden oluşmaktadır. Marka farkındalığı ile ilgili alt değişkenler; marka hatırlanırlığı ve marka tanınırlığıdır. Marka sadakati ile ilgili alt değişkenler; davranışsal sadakat ve tutumsal sadakattir. Sosyal medya kullanımı ile ilgili alt değişkenler ise; sosyal motivasyon, psikolojik motivasyon ve fonksiyonel motivasyondur.

Bu çalışmada marka farkındalığı ile hangi markanın ele alınması gerektiği konusunda spor giyim markaları üzerine durulmuştur. Türkiye'de ve Dünya'da en fazla satış değerine sahip olan lider spor giyim markaları olan Nike ve Adidas markaları dikkate alınarak katılımcıların algıları ölçülmüştür. Brandwatch adlı sosyal medya gözlem şirketinin yaptığı araştırmaya göre sosyal medya da en çok görünen markalardan 2. sırada olan Nike $(788,490) 3$. sırada ise Adidas markası $(772,520)$ yer almaktadır (Richter, 2018). Bu markaların sosyal medya üzerinde çeşitli iletişim çalışmaları yapmaları da dikkate alınmıştır. Ayrıca bu iki markanın birbirine rakip olabilecek nitelikte olması da düşünülmüştür. $\mathrm{Bu}$ kapsamda yapılan araştırma sonuçlarının ticari ve bilimsel alana katkı sağlayacağı düşünülmektedir.

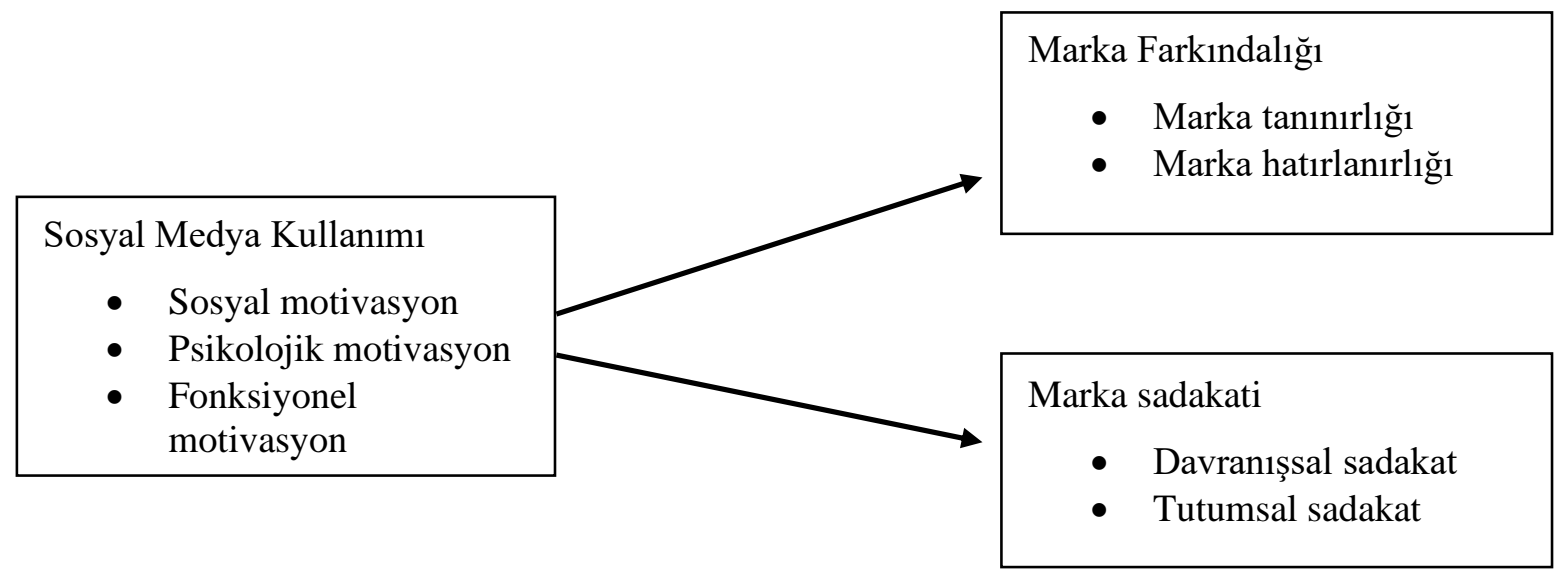

Şekil 1: Araştırma Modeli

Araştırmanın amacı ve probleminden hareketle oluşturulan temel hipotez ve alt hipotezler aşağıdaki gösterilmektedir:

Temel hipotez $\mathrm{H}_{1:}$ "Sosyal medya kullanımı, marka farkındalı̆̆ını etkilemektedir.”

Alt hipotezler:

$\mathrm{H}_{1 a, b, c}$ : Sosyal medya kullanımı boyutlarından a)sosyal motivasyon, b)psikolojik motivasyon, c)fonksiyonel motivasyon, Nike markasına göre marka tanınırlı̆̆ını etkilemektedir.

$\mathrm{H}_{1 \mathrm{~d}, \mathrm{e}, \mathrm{f}}$ : Sosyal medya kullanımı boyutlarından d)sosyal motivasyon, e)psikolojik motivasyon, f)fonksiyonel motivasyon, Adidas markasına göre marka tanınırlı̆ğını etkilemektedir.

$\mathrm{H}_{1 \mathrm{~g}, \mathrm{~h}, \mathrm{i}}$ Sosyal medya kullanımı boyutlarından g)sosyal motivasyon, h)psikolojik motivasyon, i)fonksiyonel motivasyon, Nike markasına göre marka hatırlanırlı̆ğını etkilemektedir.

$\mathrm{H}_{1 \mathrm{j}, \mathrm{k}, \mathrm{l}}$ Sosyal medya kullanımı boyutlarından j)sosyal motivasyon, $\mathrm{k}$ )psikolojik motivasyon, 1)fonksiyonel motivasyon, Adidas markasına göre marka hatırlanırlı̆ğı etkilemektedir. 


\section{Temel hipotez $\mathrm{H}_{2}$ : "Sosyal medya kullanımı, marka sadakatini etkilemektedir."}

Alt hipotezler:

$\mathrm{H}_{2 a, b, c}$ : Sosyal medya kullanımı boyutlarından a)sosyal motivasyon, b)psikolojik motivasyon, c)fonksiyonel motivasyon Nike markasına göre davranışsal sadakat algısını etkilemektedir.

$\mathrm{H}_{2 \mathrm{~d}, \mathrm{e}, \mathrm{f}}$ : Sosyal medya kullanımı boyutlarından d)sosyal motivasyon, e)psikolojik motivasyon, f)fonksiyonel motivasyon Adidas markasına göre davranışsal sadakat algısını etkilemektedir.

$\mathrm{H}_{2 \mathrm{~g}, \mathrm{~h}, \mathrm{i}}$ : Sosyal medya kullanımı boyutlarından g)sosyal motivasyon, h)psikolojik motivasyon, i)fonksiyonel motivasyon Nike markasına göre tutumsal sadakat algısını etkilemektedir.

$\mathrm{H}_{2 \mathrm{j}, \mathrm{k}, \mathrm{l}}$ : Sosyal medya kullanımı boyutlarından j)sosyal motivasyon, $\mathrm{k}$ )psikolojik motivasyon, 1)fonksiyonel motivasyon Adidas markasına göre tutumsal sadakat algısını etkilemektedir.

Sosyal medyanın marka farkındalığı ve marka sadakati üzerindeki etkisini belirlemek üzere Düzce ilinde yaşayan 20-39 yaşları arasındaki kişiler bu çalışmanın evrenini oluşturmaktadır. Bu yaş grubunun hem sosyal medyayı hem de spor giyim ürünlerini daha fazla kullandıkları varsayılmaktadır. We are social araştırma şirketinin yaptı̆̆ 1 araştırmalara göre 20-39 yaş arası kişilerin en çok sosyal medyayı kullanan yaş grupları arasında yer aldığı görülmektedir. Araştırma verileri 01.05.2019 ile 15.06.2019 tarihleri arasında toplanmıştır. Yapılan bu çalışmada kolayda örneklem yöntemi seçilmiştir. 291 kişiden toplanan veriler yüz yüze anket metodu elde edilmiştir. Genel bir kural olarak, alınacak örneklem büyüklüğünün değişken sayısının en az 5 katı, hatta 10 katı civarında olmasıdır (Karagöz ve Kösterelioğlu 2008: 85). Bu çalışmada yer alan ifadelerin toplamı 32'dir. Örneklem, ifade sayısının 5 katından fazladır. Toplanan verilere frekans, faktör, korelasyon ve regresyon analizleri uygulanmıştır. Katılımcıların temel demografik karakteristiklerini ve sosyal medyayı kullanma ile ilgili temel davranışlarını öğrenmek için frekans analizi uygulanmıştır. Nike ve Adidas markalarına yönelik katılımcıların marka farkındalığı ve sadakat algılarında değişiklik olabileceği düşüncesiyle ayrı ayrı faktör analizi yapılmıştır. Faktör analizi sonucu ortaya çıkan değişkenler arasında ilişkiyi ölçebilmek için korelasyon ve regresyon analizleri uygulanmıştır.

\section{Bulgular}

\subsection{Demografik bulgular}

$\mathrm{Bu}$ bölümde katılımcılara kategorik ölçekte yer alan ifadelerin frekans analiz sonuçları gösterilmektedir. Sırasıyla demografik bulgular, en fazla kullanılan sosyal medya aracı, sosyal medyayı kullanma amacı ve sosyal medyada geçirilen süre istatistikleri verilmektedir. 
Tablo 1: Demografik bulgular

\begin{tabular}{|c|c|c|c|}
\hline \multicolumn{2}{|c|}{ Değişkenler } & n & \% \\
\hline \multirow{3}{*}{ Cinsiyet } & Kadın & 101 & 34,7 \\
\cline { 2 - 4 } & Erkek & 190 & 65,3 \\
\hline \multirow{4}{*}{ Yaş } & $20-25$ & 66 & 22,7 \\
\cline { 2 - 4 } & $26-30$ & 119 & 40,9 \\
\cline { 2 - 4 } & $31-35$ & 49 & 16,8 \\
\cline { 2 - 4 } & $36-39$ & 57 & 19,6 \\
\hline \multirow{3}{*}{ Medeni Durum } & Evli & 95 & 32,6 \\
\cline { 2 - 4 } & Bekâr & 196 & 67,4 \\
\hline \multirow{4}{*}{ Ĕ̆itim Düzeyi } & Okur-Yazar & 4 & 1,4 \\
\cline { 2 - 4 } & İlkokul & 9 & 3,1 \\
\cline { 2 - 4 } & Ortaokul & 24 & 8,2 \\
\cline { 2 - 4 } & Lise & 137 & 47,1 \\
\cline { 2 - 4 } & Ön lisans & 89 & 30,6 \\
\cline { 2 - 4 } & Lisans & 12 & 4,1 \\
\cline { 2 - 4 } & Lisansüstü & 16 & 5,5 \\
\hline
\end{tabular}

Katılımcılara ait Tablo 1'de ki demografik bulgular incelendiğinde erkek katılımcılar $(\% 65,3)$, kadın katılımcılardan $(\% 34,7)$ daha fazla oldukları görülmektedir. Katılımcıların yaş grupları incelendiğinde \%40,9'unun 26-30, \%22,7'sinin 20-25, \%19,6'sının 36-39 ve \%16,8'sinin 31-35 yaşları arasında oldukları görülmektedir. Medeni durumların dağılımına bakıldığında \%66,4'ünün bekâr, \%32,6'sının evli oldukları görülmektedir. Katılımcıların eğitim düzeyi dağılımına bakıldı̆̆ında \%47,1 ile lise, \%30,6 ile ön lisans, $\% 8,2$ ile ortaokul, $\% 5,5$ ile lisansüstü, $\% 4,1$ ile lisans, \%3,1 ile ilkokul ve \%1,4 ile okur-yazar oldukları görülmektedir.

Günümüzde kullanılan birçok sosyal medya aracı vardır. Kullanım türleri, içeriği ve kullanım amaçlarına göre farklılık gösteren sosyal medya araçlarının araştırma evreninde bulunan frekans analiz sonuçları tablo 2'de ve tablo 4'de verilmektedir.

Tablo 2: En fazla kullanılan sosyal medya aracı

\begin{tabular}{|c|c|c|c|c|c|c|c|c|}
\hline \multirow{2}{*}{$\begin{array}{l}\text { Sosyal medya } \\
\text { türleri }\end{array}$} & \multicolumn{2}{|c|}{ En fazla kullanılan-1 } & \multicolumn{2}{|c|}{ En fazla kullanılan -2} & \multicolumn{2}{|c|}{ En fazla kullanılan -3} & \multicolumn{2}{|c|}{ Kümülatif Toplam } \\
\hline & $\mathrm{n}$ & $\%$ & $\mathrm{n}$ & $\%$ & $\mathrm{n}$ & $\%$ & $\mathrm{n}$ & $\%$ \\
\hline Instagram & 66 & 22,7 & 78 & 26,8 & 35 & 12 & 179 & 21 \\
\hline YouTube & 65 & 22,3 & 66 & 22,7 & 72 & 24,7 & 203 & 24 \\
\hline Facebook & 64 & 22,0 & 56 & 19,2 & 65 & 22,3 & 185 & 22 \\
\hline Twitter & 30 & 10,3 & 7 & 2,4 & 44 & 15,1 & 81 & 10 \\
\hline Pinterest & 19 & 6,5 & 24 & 8,2 & 15 & 5,2 & 58 & 0,7 \\
\hline Snapchat & 7 & 2,4 & 4 & 1,4 & 23 & 7,9 & 34 & 0,4 \\
\hline Linkedin & 14 & 4,8 & 26 & 8,9 & 3 & 1,0 & 43 & 0,5 \\
\hline Diğer & 26 & 26 & 3, & 10,3 & 34 & 11,7 & 63 & 0,7 \\
\hline Toplam & 291 & 100 & 291 & 100 & 291 & 100 & 846 & 100 \\
\hline
\end{tabular}

Tablo 2 incelendiğinde en fazla önem derecesine sahip sosyal medya araçlarının birbirine yakın olduğu görülmektedir. Bunlar Instagram, YouTube ve Facebook'tur. Kümülatif olarak bakıldığında ise YouTube'un en fazla tercih edilen sosyal medya aracı olduğu görülmektedir.

Tablo 3 incelendiğinde ise katılımcıların sosyal medya araçlarını kullanım amaçları görülmektedir. Önem derecesi en yüksek olan sosyal medya kullanım amacının eğlence olduğu 
görülmektedir. Daha sonra gündemi takip etmek ve arkadaşlı̆̆ın geldiği görülmektedir. Önem derecesi ikinci sırada olan sosyal medya kullanım amacında ise alış-veriş ve modanın geldiği, daha sonrasında ise arkadaşlık ve eğitimin geldiği görülmektedir. Önem derecesi üçüncü sırada olan sosyal medya kullanım amacında ise eğlence, spor ve eğitimin birbirine yakın olarak geldiği görülmektedir. Kümülatif olarak tablo 3 incelendiğinde sosyal medyanın kullanım amacının en fazla arkadaşlık ve eğlence olduğu görülmektedir. Alış-veriş ve modanın ise daha sonra geldiği görülmektedir. Araştırmanın örneklemi genel olarak düşünüldüğünde sosyal medyanın eğlence, arkadaşlık ve alış-veriş amaçlı kullandığ 1 görülmektedir.

Tablo 3: Sosyal Medyay1 Kullanma Amac1

\begin{tabular}{|l|c|c|c|c|c|c|c|c|}
\hline \multirow{2}{*}{ Amaç } & \multicolumn{2}{|c|}{ Önem derecesi-1 } & \multicolumn{2}{l|}{ Önem derecesi-2 } & \multicolumn{2}{l|}{ Önem derecesi-3 } & \multicolumn{2}{l|}{ Kümülatif } \\
\cline { 2 - 9 } & $\mathbf{n}$ & $\mathbf{\%}$ & $\mathbf{n}$ & $\mathbf{\%}$ & $\mathbf{n}$ & $\mathbf{\%}$ & $\mathbf{n}$ & \% \\
\hline Gündemi Takip Etmek & 84 & 28,9 & 2 & 0,7 & 5 & 1,7 & 91 & 10 \\
\hline Alışveriş-Moda & 16 & 5,5 & 142 & 48,8 & 16 & 5,5 & 174 & 20 \\
\hline Arkadaşlı & 75 & 25,8 & 86 & 29,6 & 42 & 14,4 & 203 & 23 \\
\hline Eğlence & 114 & 39,2 & 9 & 3,1 & 80 & 27,5 & 203 & 23 \\
\hline Ĕ̆itim & - & - & 39 & 13,4 & 68 & 23,4 & 107 & 12 \\
\hline Spor & 2 & 0,7 & 12 & 4,1 & 77 & 26,5 & 91 & 10 \\
\hline Diğer & - & - & 1 & 0,3 & 3 & 1,0 & 4 & 2 \\
\hline Toplam & 291 & 100 & 291 & 100 & 291 & 100 & 873 & 100 \\
\hline
\end{tabular}

Tablo 4'de ise katılımcıların günde sosyal medyada ortalama kaç saat zaman geçirildiği ile ilgili sonuçlar yer almaktadır. Tablo 4 incelendiğinde 1 saat ile 4 saat arasında en fazla zaman geçirildiği görülmektedir. Genel olarak incelendiğinde günde 1 saatten daha fazla zaman geçirildiği görülmektedir.

Tablo 4: Günde Ortalama Sosyal Medyada da Geçirilen Süre

\begin{tabular}{|l|c|c|}
\hline \multicolumn{1}{|c|}{ Geçirilen süre } & n & \% \\
\hline 1 saatten az & 37 & 12,7 \\
\hline 1-2 saat & 144 & 49,5 \\
\hline 3-4 saat & 87 & 29,9 \\
\hline 5-6 saat & 20 & 6,9 \\
\hline 7 saat ve üzeri & 3 & 1,0 \\
\hline Toplam & 291 & 100 \\
\hline
\end{tabular}

\subsection{Faktör analizi bulguları}

Araştırmanın bu bölümünde ankete katılanların sosyal medya kullanımı, marka farkındalığı ve marka sadakati algılarına yönelik yapılan açımlayıcı faktör analizi bulguları yer almaktadır. Analiz bulguları tablo 5'de, tablo 6'da, tablo 7'de ve tablo 8'de gösterilmektedir.

Tablo 5 incelendiğinde katılımcıların sosyal medya kullanımı algısına yönelik yapılan açımlayıcı faktör analizi Kaiser-Meyer-Olkin (KMO) örneklem yeterlilik testi ve Barlett testi sonucunun yeterli olduğu görülmektedir (KMO değeri 0,864 . Barlett testi sonucu $p<0,000)$. KMO değeri için 0.5-1.0 arası değerler kabul edilebilir değerler olarak değerlendirilirken 0.5 'in altındaki değerler faktör analizinin söz konusu veri seti için uygun olmadığı değerler olarak belirtilmektedir (Altunışık ve diğ., 2010: 266). 
Tablo 5: Sosyal Medya Kullanımı Açımlayıcı Faktör Analizi Sonuçları

\begin{tabular}{|c|c|c|c|c|c|}
\hline Faktörler & İfadeler & $\begin{array}{c}\text { Faktör } \\
\text { yük. }\end{array}$ & $\begin{array}{c}\text { Açıklanan } \\
\text { vary. }\end{array}$ & Öz değer & \begin{tabular}{|c|} 
Cronbac \\
h's \\
Alpha
\end{tabular} \\
\hline \multirow{6}{*}{ 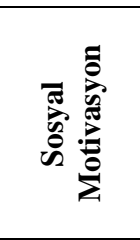 } & Sosyal medya ile harika insanlarla bir araya gelirim. & ,791 & \multirow{6}{*}{56,207} & \multirow{6}{*}{8,431} & \multirow{6}{*}{,914 } \\
\hline & Sosyal medya sayesinde başkalarını bilgilendiririm. & ,780 & & & \\
\hline & Sosyal medya kullanıcısı olarak kendimi önemli hissederim. & ,776 & & & \\
\hline & Sosyal medya ile diğer insanlarla temasa geçerim. & ,731 & & & \\
\hline & Sosyal medya ile insanlarla bir şeyler paylaşabilirim. & ,683 & & & \\
\hline & Sosyal medya sayesinde diğer insanlardan çeşitli konularda destek alırım. 914 & ,669 & & & \\
\hline \multirow{5}{*}{ 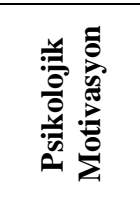 } & Sosyal medyada zaman geçirmek eğlencelidir. & ,901 & \multirow{5}{*}{10,696} & \multirow{5}{*}{1,604} & \multirow{5}{*}{,910 } \\
\hline & Sosyal medyada ilgi çekici içerikler bulunmaktadır. & ,830 & & & \\
\hline & Sosyal medyada zaman geçirmek kolaydır. & ,765 & & & \\
\hline & Sosyal medya kullanımı bir topluluğa aidiyet hissi vermektedir. & ,735 & & & \\
\hline & Sosyal medya kullanımı heyecan vericidir. 910 & ,664 & & & \\
\hline \multirow{4}{*}{ 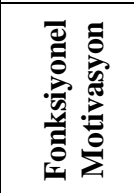 } & Sosyal medya ile bir şeyin nasıl yapıldığını öğrenirim. & ,868 & \multirow{4}{*}{8,161} & \multirow{4}{*}{1.224} & \multirow{4}{*}{,905 } \\
\hline & Sosyal medya sayesinde gündem ile ilgili güncel bilgileri alırım. & ,774 & & & \\
\hline & Sosyal medya sayesinde ürünler ile ilgili faydalı bilgiler alırım. & ,753 & & & \\
\hline & Sosyal medyada insanlarla kurduğum iletişimde kendimi özgür hissederim. 905 & ,733 & & & \\
\hline $\mathrm{D}$ & $\begin{array}{l}\text { Kaiser-Meyer-Olkin Measure of Sampling Adequacy: } 0,864 \text { A } \\
\text { Sphericity: } 0,000 \quad \text { Rotation Method: Varimax Aç1klan }\end{array}$ & S & 64 & 8 Bar & Test $\mathrm{c}$ \\
\hline
\end{tabular}

Tablo 5 incelendiğinde sosyal medya kullanımı algısı ile ilgili yapılan faktör analizi için varimax döndürme tekniği ve temel bileşenler analizi kullanıldığı anlaşılmaktadır. Faktör analizinde 7. İfade iki faktör de yükleri birbirine yakın olduğu için ("Sosyal medya uygulamalarını kullanmak kolaydır" faktör yükleri 0,622 ile 0,541) analizden çıarılmıştır. Bu doğrultuda sosyal medya kullanımı algısına yönelik analizde 15 ifade kalmıştır. Bu 15 ifadenin toplamda üç faktör altında bir araya geldikleri Tablo 5'de görülmektedir. Ölçekte yer alan ifadeler birlikte düşünüldüğünde öz değeri 8,431 olan faktör "Sosyal Motivasyon"; öz değeri 1,604 olan faktör "Psikolojik Motivasyon"; öz değeri 1,224 olan faktör ise "Fonksiyonel Motivasyon" olarak isimlendirilmiştir. Tablo 5'e bakıldığında toplam açıklanan varyansın \%75 düzeyinde olduğu anlaşılmaktadır. Bu bulguya göre ankette yer alan ifadelerin sosyal medya kullanımı algısını açıklamada üç faktörün kabul edilebilir düzeyde olduğu anlaşılmaktadır.

Tablo 6'da ve tablo 7'de ise katılımcıların marka farkındalığı ile ilgili yapılan faktör analizi çıktıları görülmektedir. Tablo 6'da Nike markasına göre katılımcıların marka farkındalığ ölçülmüştür. Tablo 7'de ise Adidas markasına göre katılımcıların marka farkındalığı algıları ölçülmüştür. Tablo 6'ya bakıldığında Nike için yapılan marka farkındalığı algısı açımlayıcı faktör analizi KMO ve Barlett testi sonucunun yeterli düzeyde olduğu görülmektedir (KMO değeri 0,623. Barlett testi sonucu $\mathrm{p}<0,000)$. Açımlayıcı faktör analizi için varimax döndürme tekniği ve temel bileşenler analizi kullanılmıştır. Analizde herhangi bir ifade çıkarılmamıştır. Analiz sonucuna göre ifadelerin iki faktör altında toplandıkları Tablo 6'da anlaşılmaktadır. Ölçekte yer alan ifadeler birlikte düşünüldüğünde öz değeri 3,421 olan faktör "marka tanınırlığı"; öz değeri 2,695 olan faktör ise "marka hatırlanılırlığı" olarak isimlendirilmiştir. Tablo 6'ya bakıldığında toplam açıklanan Varyansın \%76 düzeyinde olduğu görülmektedir. Bu bulguya göre ankette yer alan ifadelerin marka farkındalığı algısını açıklamada iki faktörün kabul edilebilir düzeyde olduğu anlaşılmaktadır. 
Tablo 6: Marka Farkındalığı Açımlayıcı Faktör Analizi Sonuçları (Nike)

\begin{tabular}{|c|c|c|c|c|c|}
\hline Faktörler & İfadeler & $\begin{array}{l}\text { Faktör } \\
\text { yük. }\end{array}$ & $\begin{array}{c}\text { Açıklanan } \\
\text { vary. }\end{array}$ & $\begin{array}{c}\text { Öz } \\
\text { değer }\end{array}$ & $\begin{array}{l}\text { Cronbach's } \\
\text { Alpha }\end{array}$ \\
\hline \multirow{4}{*}{ 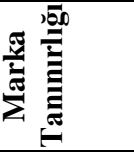 } & Nike markasını kullandığım sosyal ağlardan takip ederim. & ,948 & \multirow{4}{*}{42,764} & \multirow{4}{*}{3,421} & \multirow{4}{*}{,882 } \\
\hline & Spor ayakkabıya ihtiyacım olduğunda Nike markasını tercih ederim. & ,897 & & & \\
\hline & Sosyal medyada Nike logolarıyla karşılaşıyorum. & ,855 & & & \\
\hline & Nike markalarının sosyal medyada popüler olması benim için önemlidir. & ,753 & & & \\
\hline \multirow{4}{*}{ 昰 } & $\begin{array}{l}\text { Sosyal medyada diğer rakip markalar arasından Nike markalarının } \\
\text { logolarını tanıyabilirim. }\end{array}$ & ,907 & \multirow{4}{*}{33,685} & \multirow{4}{*}{2,695} & \multirow{4}{*}{,879 } \\
\hline & Nike markasının paylaşımlarıyla sosyal medyada daha çok karşılaşırım. & ,850 & & & \\
\hline & Sosyal medyada gördüğüm sloganların Nike'a ait olduğunu bilirim. & 846 & & & \\
\hline & $\begin{array}{l}\text { Nike markalarıyla sosyal medyada karşılaştığımda satın alma isteği } \\
\text { duyarım. } 879\end{array}$ & ,822 & & & \\
\hline \multicolumn{6}{|c|}{ Değerlendirme Kriterleri: Kaiser-Meyer-Olkin Measure of Sampling Adequacy: 0,623 Approx. Chi-Square:1838,677 } \\
\hline & Bartlett's Test of Sphericity: 0,000 & \multicolumn{4}{|c|}{ Açıklanan varyans: 76,449} \\
\hline
\end{tabular}

Tablo 7 incelendiğinde ise Adidas markasına yönelik marka farkındalığı açımlayıcı faktör analizi bulguları yer almaktadır. Adidas markası için yapılan marka farkındalığı algısı açımlayıcı faktör analizi KMO ve Barlett testi sonucunun yeterli olduğu anlaşılmaktadır (KMO değeri 0,702. Barlett testi sonucu $\mathrm{p}<0,000)$.

Tablo 7: Marka Farkındalığı Açımlayıcı Faktör Analizi Sonuçları (Adidas)

\begin{tabular}{|c|c|c|c|c|c|}
\hline Faktörler & İfadeler & $\begin{array}{l}\text { Faktör } \\
\text { yük. }\end{array}$ & $\begin{array}{c}\text { Açıklanan } \\
\text { vary. }\end{array}$ & $\begin{array}{c}\text { Öz } \\
\text { değer }\end{array}$ & $\begin{array}{c}\text { Cronbach's } \\
\text { Alpha }\end{array}$ \\
\hline \multirow{4}{*}{ 急 } & $\begin{array}{l}\text { Adidas markalarıyla sosyal medyada karşılaştı̆̆ımda satın alma isteği } \\
\text { duyarım. }\end{array}$ & 870 & \multirow{4}{*}{39,657} & \multirow{4}{*}{3,173} & \multirow{4}{*}{890} \\
\hline & $\begin{array}{l}\text { Sosyal medyada diğer rakip markalar arasından Adidas markalarının } \\
\text { logolarını tanıyabilirim. }\end{array}$ &, 828 & & & \\
\hline & Sosyal medyada Adidas logolarıyla karşılaşıyorum. & ,826 & & & \\
\hline & Spor ayakkabıya ihtiyacım olduğunda Adidas markasını tercih ederim. & ,814 & & & \\
\hline \multirow{4}{*}{ 旁 } & Sosyal medyada gördüğüm sloganların Adidas'a ait olduğunu bilirim. &, 811 & \multirow{4}{*}{28,819} & \multirow{4}{*}{2,306} & \multirow{4}{*}{,757 } \\
\hline & Adidas markasını kullandığım sosyal ağlardan takip ederim. & ,751 & & & \\
\hline & $\begin{array}{l}\text { Adidas markalarının sosyal medyada popüler olması benim için } \\
\text { önemlidir. }\end{array}$ & ,730 & & & \\
\hline & $\begin{array}{l}\text { Adidas markasının paylaşımlarıyla sosyal medyada daha çok } \\
\text { karşılaşırım. }\end{array}$ &, 556 & & & \\
\hline
\end{tabular}

Tablo 7'ye bakıldığında faktör analizi için varimax döndürme tekniği ve temel bileşenler analizinin kullanıldığı anlaşılmaktadır. Anketten herhangi bir ifade çıkarılmamıştır. Ölçekte yer alan ifadelerin iki faktör altında toplandıkları görülmektedir. Ölçekte ki ifadeler birlikte düşünüldüğünde öz değeri 3,173 olan faktör "marka tanınırlığı"; öz değeri 2,306 olan faktör ise "marka hatırlanılırlığı” olarak isimlendirilmiştir. Tablo 7'ye bakıldığında toplam açıklanan varyansın \%68 düzeyinde olduğu anlaşılmaktadır. Bu bulgular ışığında ankette yer alan ifadelerin marka farkındalığını algısını açıklamada iki faktörün kabul edilebilir düzeyde olduğu anlaşılmaktadır.

Tablo 8 ve tablo 9'da ankete katılanların Nike ve Adidas marksa dakati algılarına yönelik yapılan açımlayıcı faktör analizi bulguları görülmektedir. 
Tablo 8: Marka Sadakati Açımlayıcı Faktör Analizi Sonuçları (Nike)

\begin{tabular}{|c|c|c|c|c|c|}
\hline Faktörler & Iffadeler & $\begin{array}{l}\text { Faktör } \\
\text { yük. }\end{array}$ & $\begin{array}{c}\text { Açılklanan } \\
\text { vary. }\end{array}$ & $\begin{array}{c}\text { Öz } \\
\text { değer }\end{array}$ & $\begin{array}{l}\text { Cronbach's } \\
\text { Alpha }\end{array}$ \\
\hline \multirow{3}{*}{ 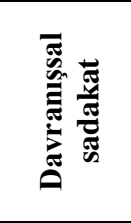 } & $\begin{array}{l}\text { Nike markasına ihtiyacım olduğunda gittiğim mağazada } \\
\text { bulunmuyorsa onu baska mağazadan alırım. }\end{array}$ & ,840 & \multirow{3}{*}{40,102} & \multirow{3}{*}{2,005} & \multirow{3}{*}{,715 } \\
\hline & $\begin{array}{l}\text { Başka bir marka daha cazip firsatlar sunarsa, Nike yerine o markayı } \\
\text { tercih ederim. }\end{array}$ & ,822 & & & \\
\hline & $\begin{array}{l}\text { Nike markasıyla ilgili olumsuz yorum yapan birisi olursa markaları } \\
\text { savunurum. }\end{array}$ & ,709 & & & \\
\hline \multirow{2}{*}{ 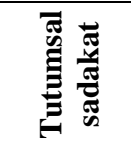 } & $\begin{array}{l}\text { Hangi markadan spor ayakkabı satın alacağına karar veremeyen birisi } \\
\text { olsa Nike markasını tavsive ederim. }\end{array}$ & ,868 & \multirow{2}{*}{28,237} & \multirow{2}{*}{1,412} & \multirow{2}{*}{,780 } \\
\hline & $\begin{array}{l}\text { Nike markasıyla ilgili olumsuz yorum yapan birisi olursa ona } \\
\text { inanırım. }\end{array}$ & ,816 & & & \\
\hline \multicolumn{3}{|c|}{ Değerlendirme Kriterleri: Kaiser-Meyer-Olkin Measure of Sampling Adequacy: 0,522 } & \multicolumn{3}{|c|}{ Approx. Chi-Square: 313,185} \\
\hline & Bartlett's Test of Sphericity: 0,000 & \multicolumn{3}{|c|}{ Açıklanan varyans: 68,338} & \\
\hline
\end{tabular}

Tablo 8'de Nike markasına göre katılımcıların marka sadakati algıları ölçülmüştür. Tablo 9'da ise Adidas markasına göre katılımcıların marka sadakati algıları ölçülmüştür. Tablo 8'e bakıldığında Nike için yapılan marka sadakati algısı açımlayıcı faktör analizi KMO ve Barlett testi bulgularının yeterli olduğu anlaşılmaktadır (KMO değeri 0,522. Barlett testi sonucu p<0,000). Faktör analizi için varimax döndürme tekniği ve temel bileşenler analizi kullanılmıştır. Analizde 1. ifade ("Nike markasından spor ayakkabı almaya devam etme niyetindeyim") ve 7. ifade ("Arkadaşlarıma sık sık Nike markasının ne kadar iyi olduğunu söylerim”) düşük faktör yüküne sahip olduğu için analizden çıkarılmıştır. Kalan ifadelerin iki faktör altında bir araya geldikleri tablo 8'de anlaşılmaktadır. Ölçekte ki ifadeler birlikte düşünüldüğünde öz değeri 2,005 olan faktör "davranıșsal sadakat"; öz değeri 1,412 olan faktör ise "tutumsal sadakat" olarak isimlendirilmiştir. Tablo 8'e bakıldığında toplam açıklanan varyansın \%68 düzeyinde olduğu anlaşılmaktadır. Bu bulgular ışı̆̆ında ankette yer alan ifadelerin marka sadakatini açıklamada iki faktörün kabul edilebilir düzeyde olduğu anlaşılmaktadır.

Tablo 9'a bakıldığında ise Adidas için yapılan marka sadakati algısı faktör analizi KMO ve Barlett testi bulgusunun yeterli olduğu anlaşılmaktadır (KMO değeri 0,609. Barlett testi sonucu $\mathrm{p}<0,000)$. Faktör analizi için varimax döndürme tekniği ve temel bileşenler analizi kullanılmıştır. Analizde herhangi bir ifade çıkarılmamıştır. İfadelerin iki faktör altında bir araya geldiği tablo 9'da anlaşılmaktadır. Ölçekte ki ifadeler birlikte düşünüldüğünde öz değeri 2,615 olan faktör "tutumsal sadakat"; öz değeri 1,623 olan faktör ise "davranışsal sadakat" olarak isimlendirilmiştir. Tablo 9'a bakıldığında toplam açıklanan varyansın \%60 düzeyinde olduğu anlaşılmaktadır. Bu bulgular 1şı̆̆ında ankette yer alan ifadelerin marka sadakatini açıklamada iki faktörün kabul edilebilir düzeyde olduğu anlaşılmaktadır. 
Tablo 9: Marka Sadakati Açımlayıcı Faktör Analizi Sonuçları (Adidas)

\begin{tabular}{|c|c|c|c|c|c|}
\hline Faktörler & İfadeler & $\begin{array}{l}\text { Faktör } \\
\text { yük. }\end{array}$ & $\begin{array}{c}\text { Açılklanan } \\
\text { vary. }\end{array}$ & $\begin{array}{c}\text { Öz } \\
\text { değer }\end{array}$ & $\begin{array}{l}\text { Cronbach's } \\
\text { Alpha }\end{array}$ \\
\hline \multirow{4}{*}{ 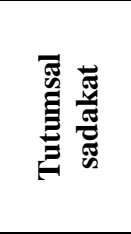 } & Adidas markasıyla ilgili olumsuz yorum yapan birisi olursa ona inanırım. &, 848 & \multirow{4}{*}{37,362} & \multirow{4}{*}{2,615} & \multirow{4}{*}{,766 } \\
\hline & Arkadaşlarıma sık sık Adidas markasının ne kadar iyi olduğunu söylerim. & ,838 & & & \\
\hline & $\begin{array}{l}\text { Hangi markadan spor ayakkabı satın alacağına karar veremeyen birisi olsa } \\
\text { Adidas markasını tavsiye ederim. }\end{array}$ &, 818 & & & \\
\hline & $\begin{array}{l}\text { Başka bir marka daha cazip firsatlar sunarsa, Adidas yerine o markayı } \\
\text { tercih ederim. }\end{array}$ &, 560 & & & \\
\hline \multirow{3}{*}{ 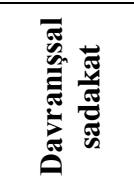 } & $\begin{array}{l}\text { Adidas markasına ihtiyacım olduğunda gittiğim mağazada bulunmuyorsa } \\
\text { onu başka mağazadan alırım. }\end{array}$ & ,864 & \multirow{3}{*}{23,184} & \multirow{3}{*}{1,623} & \multirow{3}{*}{, 802} \\
\hline & $\begin{array}{l}\text { Adidas markasıyla ilgili olumsuz yorum yapan birisi olursa markaları } \\
\text { savunurum. }\end{array}$ & ,787 & & & \\
\hline & \begin{tabular}{|l|l|} 
Adidas markasından spor ayakkabı almaya devam etme niyetindeyim. \\
\end{tabular} & ,516 & & & \\
\hline \multicolumn{6}{|c|}{ Değerlendirme Kriterleri: Kaiser-Meyer-Olkin Measure of Sampling Adequacy: 0,609 } \\
\hline & Bartlett's Test of Sphericity: 0,000 & \multicolumn{4}{|c|}{ Açıklanan varyans: 60,546} \\
\hline
\end{tabular}

\subsection{Korelasyon analizi bulguları}

$\mathrm{Bu}$ bölümde katılımcıların sosyal medya kullanımı algısı, marka farkındalığı ve marka sadakati arasındaki ilişkileri incelemek için korelasyon analizi uygulanmışıtır. Korelasyon analizi bulguları tablo-10 ve tablo 11 'de görülmektedir. Nike ve Adidas markaları için sosyal medya kullanımı algısı, marka farkındalığı ve marka sadakati değişkenlerinin alt boyutları arasında çeşitli düzeylerde anlamlı ve pozitif ilişkilerin var olduğu anlaşılmaktadır. Korelasyon analizinde $0,00-0,30$ arası değerler düşük düzey ilişkiye, $0,30-0,70$ arası değerler orta düzey ilişkiye ve 0,70-1,00 arası değerler ise yüksek düzey ilişkiye işaret etmektedir (Büyüköztürk, 2015: 32).

Tablo 10: Korelasyon analizi sonuçları (Nike)

\begin{tabular}{|c|c|c|c|c|c|c|c|}
\hline Boyutlar & 1. & 2. & 3. & 4. & 5. & 6. & 7. \\
\hline Sosyal motivasyon & 1 &, $627^{* *}$ &, $660^{* *}$ &, $568^{* *}$ &, 049 & $\mathbf{7 4 3}^{* *}$ & $163^{* * *}$ \\
\hline 2. Psikolojik motivasyon & & 1 &, $633^{* *}$ & ,327** & $215^{* *}$ & $477^{* *}$ & $187^{\text {*** }}$ \\
\hline 3. Fonksiyonel motivasyon & & & 1 & ,394** &, 020 &, $507^{* *}$ &,- 032 \\
\hline 4. Marka Tanınırlığı & & & & 1 &, 100 &, $607^{* *}$ & ,068 \\
\hline 5. Marka Hatırlanırlığı & & & & & 1 & ,048 &, 095 \\
\hline 6. Davranışsal sadakat & & & & & & 1 & $120 *$ \\
\hline 7. $\quad$ Tutumsal sadakat & & & & & & & 1 \\
\hline
\end{tabular}

Tablo 10'a bakıldığında Nike markası için sosyal medya kullanımı algısının alt boyutlarından sosyal motivasyon ile marka tanınırlığı arasında orta düzeyde ilişki görülürken, davranışsal sadakat arasında yüksek düzeyde ilişkinin olduğu anlaşılmaktadır. Tutumsal sadakat arasında ise zayıf ve pozitif yönlü ilişkinin bulunduğu görülmektedir. Sosyal medya kullanımı algısının alt boyutlarından psikolojik motivasyon ile marka tanınırlı̆̆ arasında orta düzeyde ilişki varken, marka hatırlanırlığı arasında ise zayıf ve pozitif yönlü ilişki olduğu anlaşılmaktadır. Psikolojik motivasyon ile davranışsal sadakat arasında ise orta düzey ve pozitif yönlü bir ilişki varken, tutumsal sadakat arasında zayıf ve pozitif yönlü ilişki olduğu görülmektedir. Sosyal medya kullanımı algısının alt boyutlarından fonksiyonel motivasyon ile marka tanınırlığı arasında ve davranışsal sadakat arasında orta düzeyde pozitif yönlü ilişki olduğu anlaşılmaktadır. Bu bulgular ışığında sosyal medya kullanımı algısı ile davranışsal sadakat ve marka tanınırlığı arasında daha fazla ilişskinin olduğu anlaşılmaktadır.

Tablo-11 incelendiğinde ise Adidas markası için sosyal medya kullanımı algısı, marka farkındalığı ve marka sadakati değişkenlerinin alt boyutları arasındaki ilişki sonuçları görülmektedir. 
Sosyal medya kullanımı algısının alt boyutlarından sosyal motivasyon ile marka hatırlanırlığı ve tutumsal sadakat arasında yüksek düzeyde ve pozitif ilişki görülürken, davranışsal sadakat arasında zayıf ve pozitif yönlü ilişki olduğu anlaşılmaktadır. Sosyal medya kullanımı algısının alt boyutlarından psikolojik motivasyon ile marka tanınırlığ 1 arasında zayıf düzeyde, marka hatırlanırlığı ve tutumsal sadakat arasında orta düzeyde ve davranışsal sadakat arasındaise zayıf ve pozitif yönlü ilişki olduğu anlaşılmaktadır. Sosyal medya kullanımı algısının alt boyutlarından fonksiyonel motivasyon ile marka hatırlanırlığı ve tutumsal sadakat arasında orta düzeyde ve pozitif yönlü ilişki olduğu görülmektedir. Bu bulgular 1şığında sosyal medya kullanımı algısı ile tutumsal sadakat ve marka hatırlanırlığı arasında daha fazla ilişkinin olduğu görülmektedir. Her iki marka karşılaştırıldığında sosyal medya kullanımı-marka farkındalı̆̆ 1 ilişkisinde Adidas markası için hatırlanırlığın ve Nike markası için tanınırlığın ön plana çıktığı anlaşılmaktadır. Sosyal medya kullanımı-marka sadakati ilişkisinde ise Adidas markası için tutumsal sadakatin ve Nike markası için davranışsal sadakatin ön plana çıktığı anlaşılmaktadır.

Tablo 11: Korelasyon analizi sonuçları (Adidas)

\begin{tabular}{|c|c|c|c|c|c|c|c|}
\hline Boyutlar & 1. & 2. & 3. & 4. & 5. & 6. & 7. \\
\hline 1. Sosyal Motivasyon & 1 &, $627^{* * *}$ & $660^{* *}$ &, 034 & $809^{* *}$ & $153^{* *}$ & $0,867^{* *}$ \\
\hline 2. Psikolojik Motivasyon & & 1 & $633^{* *}$ &, $213^{* *}$ &, $525^{* *}$ & $252^{* *}$ &, $510^{* *}$ \\
\hline 3. Fonksiyonel Motivasyon & & & 1 &, 014 & $528^{* *}$ & 069 & $550^{* *}$ \\
\hline 4. Marka Tanınırlığ 1 & & & & 1 &, 092 &, $796^{* *}$ & 005 \\
\hline 5. Marka Hatırlanırlığ1 & & & & & 1 & $143^{*}$ & $875^{* *}$ \\
\hline 6. Davranıșsal Sadakat & & & & & & 1 & $183^{* *}$ \\
\hline 7. Tutumsal Sadakat & & & & & & & \\
\hline
\end{tabular}

\subsection{Regresyon analizi bulguları}

Bu bölümde sosyal medya kullanımının marka farkındalığı ve marka sadakati üzerine etkileri analiz edilmektedir. Araştırma modelinde yer alan bağımlı değişkenler tek tek (marka hatırlanırlı̆̆ı, marka tanınırlığı, tutumsal sadakat, davranışsal sadakat,) bağımsız değişkenler ise (sosyal, psikolojik ve fonksiyonel motivasyon) korelasyon analiz çıktılarına göre çoklu regresyon analizine tabi tutulmuştur. Bu doğrultuda aşağıda sırasıyla çoklu doğrusal regresyon analizleri yer almaktadır. Tablo 12 'de Nike markasına göre sosyal medya kullanımın marka farkındalığı ve marka sadakati üzerine etkileri incelenmiştir.

Tablo 12 incelendiğinde Nike markası için "sosyal, psikolojik ve fonksiyonel motivasyon" ile "marka tanınırlığı” arasında orta düzeyde ve pozitif (sırasıyla; 0,$568 ; 0,327 ; 0,394$ ) ilişki olduğu görülmektedir. Tolerance değerleri arasında 0.20 'den daha düşük bir değer ve VIF değerleri arasında 10 'dan yüksek bir değer olmadığ 1 için bağımsız değişkenler arasında çoklu bağlantılılığın söz konusu olmadığ söylenebilir. Durbin-Watson katsayısının ise $(1,248)$ hata terimleri ve bağımsız değişkenler arasında sorunlu bir ilişkinin olmadığını göstermektedir. Bağımlı ve bağımsız değişkenler arasında orta düzeyde, anlamlı bir ilişki mevcuttur ( $\left.\mathrm{R}: 0,571, \mathrm{R}^{2}: 0,326, \mathrm{p}: 0,000\right)$. Standardize edilmiş regresyon katsayılarına $(\beta)$ göre, sosyal medya kullanımı alt boyutlarının marka tanınırlığı üzerindeki göreli önem siras1; "sosyal motivasyon, psikolojik motivasyon ve fonksiyonel motivasyon" şeklindedir. T-testi sonuçlarına bakıldığında ise sosyal motivasyonun marka tanınırlığı üzerinde anlamlı bir etkisinin olduğu anlaşılmaktadır. Bu bulgular ışığında; $H_{l a}$ hipotezi kabul edilmiştir.

Tablo 12 incelendiğinde "psikolojik motivasyon" ile "marka hatırlanırlı̆̆ı" arasında düşük pozitif (R: 0,215) bir korelasyon olduğu görülmektedir. Bağımlı ve bağımsız değişken arasında düşük düzeyde, anlamlı bir ilişki mevcuttur $\left(\mathrm{R}^{2}: 0,046\right.$, p: 0,000). T-testi sonucuna bakıldığında ise psikolojik motivasyonun marka hatırlanırlığı üzerinde anlamlı bir etkisinin olduğu anlaşılmaktadır. Bu bulgular ışığında; $H_{l h}$ hipotezi kabul edilmiştir. 
Tablo 12 incelendiğinde "sosyal, psikolojik ve fonksiyonel motivasyon" ile "davranışsal sadakat" arasında yüksek ve orta düzeyde pozitif (sırasıyla; 0,$743 ; 0,477 ; 0,507$ ) bir korelasyon olduğu görülmektedir. Bağımlı ve bağımsız değişkenler arasında orta düzeyde, anlamlı bir ilişki mevcuttur (R: 0,743, $\left.R^{2}: 0,552, p: 0,000\right)$. Standardize edilmiş regresyon katsayılarına $(\beta)$ göre, sosyal medya kullanımı alt boyutlarının davranışsal sadakat üzerindeki göreli önem sırası; "sosyal motivasyon, fonksiyonel motivasyon ve psikolojik motivasyon" şeklindedir. T-testi sonuçlarına bakıldığında ise sosyal motivasyonun davranışsal sadakat üzerinde anlamlı bir etkisinin olduğu görülmektedir. Bu bulgular ışığında; $H_{2 a}$ hipotezi kabul edilmiştir.

Tablo 12: Sosyal medya kullanımı, marka farkındalığı ve marka sadakati Çoklu Regresyon Analiz Sonuçları (Nike)

\begin{tabular}{|c|c|c|c|c|c|c|c|c|c|}
\hline Değişkenler & B & $\begin{array}{l}\text { Std. } \\
\text { Hatab }\end{array}$ & Beta & $\mathbf{T}$ & $\mathbf{P}$ & $\begin{array}{l}\text { İkili } \\
\text { R }\end{array}$ & $\begin{array}{l}\text { Kismi } \\
\text { R }\end{array}$ & Tol. & VIF \\
\hline Sabit & ,912 &, 166 & - & 5,504 &, 000 & - & - & - & - \\
\hline Sosyal motivasyon & ,502 & 061 &, 572 & 8,280 &, 000 &, 568 & ,439 & ,491 & 2,036 \\
\hline Psikolojik motivasyon &,- 055 &, 053 &,- 070 & $-1,043$ & ,298 &, 327 &,- 061 &, 522 & 1,917 \\
\hline Fonksiyonel motivasyon &, 047 &, 054 & ,061 &, 870 &, 385 & ,394 &, 051 & ,485 & 2,061 \\
\hline \multicolumn{10}{|c|}{ Bağımlı Değişken: Marka tanınırlığı } \\
\hline $\mathrm{R}^{2}: 0,326$ & \multicolumn{2}{|c|}{$F_{(3-287)}: 46,341$} & \multicolumn{2}{|l|}{ P: 0,000} & \multicolumn{3}{|c|}{ Durbin-Watson: 1,248} & \multicolumn{2}{|c|}{ Metod: Enter } \\
\hline Sabit &, 173 &, 188 & - & ,921 &, 358 & - & - & - & - \\
\hline Sosyal motivasyon & ,876 & 069 &, 720 & 12,778 &, 000 & ,743 & ,602 & ,491 & 2,036 \\
\hline Psikolojik motivasyon & 010 &, 060 &, 009 &, 172 &, 864 & 477 & 010 &, 522 & 1,917 \\
\hline Fonksiyonel motivasyon &, 027 & ,061 &, 025 & 447 & 655 &, 507 & 026 & 485 & 2,061 \\
\hline \multicolumn{10}{|c|}{ Bağımlı Değişken: Davranışsal sadakat } \\
\hline $\mathrm{R}^{2}: 0,552$ & \multicolumn{2}{|c|}{$\mathrm{F}_{(3-287)}: 117,973$} & \multicolumn{2}{|c|}{ P: 0,000} & \multicolumn{3}{|c|}{ Durbin-Watson: 1,505} & od: Er & \\
\hline Sabit & 1,524 &, 210 & - & 7,270 &, 000 & - & - & - & - \\
\hline Sosyal motivasyon & 072 & 071 & ,076 & 1,024 & ,307 &, 163 &, 060 & 607 & 1,648 \\
\hline Psikolojik motivasyon &, 119 & ,064 &, 139 & 1,879 &, 061 &, 187 &, 110 & 607 & 1,648 \\
\hline \multicolumn{10}{|c|}{ Bağımlı Değişken: Tutumsal sadakat } \\
\hline $\mathrm{R}^{2}: 0,038$ & \multicolumn{2}{|c|}{$\mathrm{F}_{(2-288)}: 5,764$} & P: 0,004 & \multicolumn{4}{|c|}{ Durbin-Watson:0,845 } & \multicolumn{2}{|c|}{ Metod: Enter } \\
\hline Sabit & 1,625 &, 181 & - & 8,988 &, 000 & & & & \\
\hline Psikolojik motivasyon &, 183 & ,049 & ,215 & 3,749 &, 000 & & & & \\
\hline \multicolumn{10}{|c|}{ Bağımlı Değişken: Marka hatırlanırlığı } \\
\hline $\mathrm{R}^{2}: 0,046$ & \multicolumn{2}{|c|}{$\mathrm{F}_{(1-289)}: 14,055$} & \multicolumn{2}{|l|}{ P: 0,000} & \multicolumn{3}{|c|}{ Durbin-Watson:0,845 } & d: En & \\
\hline
\end{tabular}

Tablo 12 incelendiğinde "sosyal ve psikolojik motivasyon" ile "tutumsal sadakat" arasında düşük düzeyde pozitif (sırasıyla; 0,163; 0,187) ilişki olduğu anlaşılmaktadır. Bağımlı ve bağımsız değişkenler arasında orta düzeyde ve anlamlı bir ilişki mevcuttur (R: $0,196, R^{2}: 0,038$, p: 0,004). Standardize edilmiş regresyon katsayılarına $(\beta)$ göre, sosyal medya kullanımı alt boyutlarının tutumsal sadakat üzerindeki göreli önem sırasi; "psikolojik motivasyon ve sosyal motivasyon" şeklindedir. Regresyon katsayılarının anlamlılı̆̆ına ilişkin t-testi sonuçları incelendiğinde ise psikolojik motivasyonun tutumsal sadakat üzerinde anlamlı bir etkisinin olduğu görülmektedir. $\mathrm{Bu}$ bulgular ışığında $H_{2 h}$ hipotezi kabul edilmiştir.

Tablo 13'de Adidas markasına göre sosyal medya kullanımının marka farkındalığ 1 ve marka sadakati üzerine etkileri incelenmiştir. Tablo 13 incelendiğinde Adidas markası için "sosyal, psikolojik ve fonksiyonel motivasyon" ile "marka hatırlanırlığı" arasında yüksek ve orta düzeyde pozitif (sırasıyla; 0,$809 ; 0,525 ; 0,528)$ ilişki olduğu anlaşılmaktadır. Tolerance değerleri arasında 
0.20 'den daha düşük bir değer ve VIF değerleri arasında 10'dan yüksek bir değer olmadığ için bağımsız değişkenler arasında çoklu bağlantılılığın olmadığı söylenebilir. Durbin-Watson katsayısı $(1,809)$ hata terimleri ve bağımsız değişkenler arasında sorunlu bir ilişkinin olmadığını göstermektedir. Bağımlı ve bağımsız değişkenler arasında orta düzeyde, anlamlı bir ilişki mevcuttur (R: $\left.0,809, R^{2}: 0,655, p: 0,000\right)$. Standardize edilmiş regresyon katsayılarına $(\beta)$ göre, sosyal medya kullanımı alt boyutlarının marka hatırlanırlığı üzerindeki göreli önem sırası; "sosyal motivasyon, psikolojik motivasyon ve fonksiyonel motivasyon" şeklindedir. T-testi sonuçları incelendiğinde ise sosyal motivasyonun marka hatırlanırlı̆ğ üzerinde anlamlı bir etkisinin olduğu görülmektedir. $\mathrm{Bu}$ bulgular 1şığında; $H_{l j}$ hipotezi kabul edilmiştir.

Tablo 13: Sosyal medya kullanımı, marka farkındalığı ve marka sadakati Çoklu Regresyon Analiz Sonuçları (Adidas)

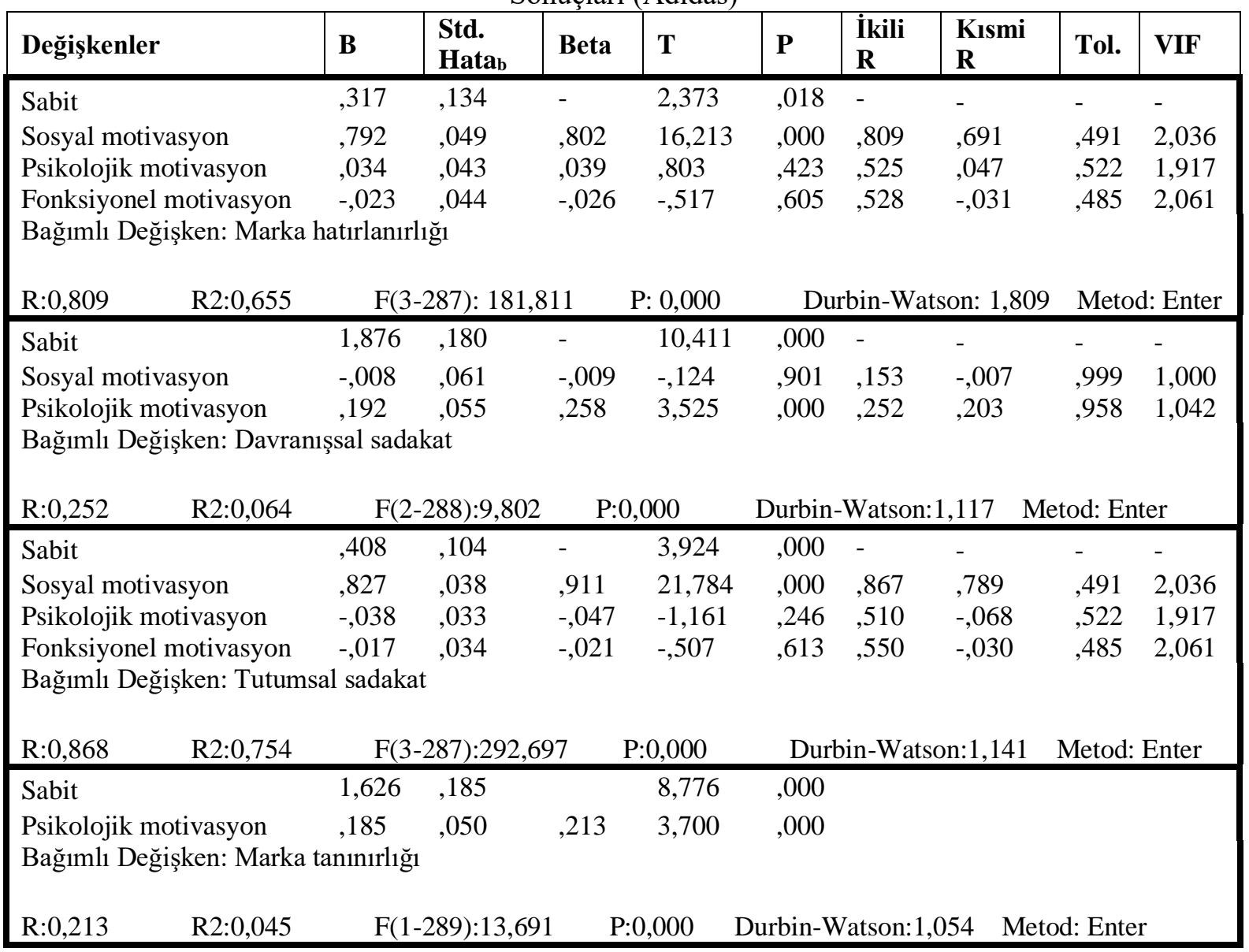

Tablo 13 incelendiğinde "psikolojik motivasyon" ile "marka tanınırlı̆̆ı" arasında düşük pozitif (R: 0,213) ilişki olduğu anlaşılmaktadır. Bağımlı ve bağımsız değişken arasında düşük düzeyde, anlamlı bir ilişki mevcuttur $\left(\mathrm{R}^{2}: 0,045\right.$, p: 0,000). T-testi sonucu incelendiğinde ise psikolojik motivasyonun marka tanınırlığı üzerinde anlamlı bir etkisinin olduğu görülmektedir. $\mathrm{Bu}$ bulgular ışığında; $H_{l e}$ hipotezi kabul edilmiştir.

Tablo 13 incelendiğinde "sosyal motivasyon ve psikolojik motivasyon" ile "davranışsal sadakat" arasında yüksek ve orta düzeyde pozitif (sırasıyla; 0,153;0,252) ilişki olduğu anlaşılmaktadır. Bağımlı ve bağımsız değişkenler arasında orta düzeyde, anlamlı bir ilişki mevcuttur (R: 0,252, $R^{2}: 0,064$, p: 0,000). Standardize edilmiş regresyon katsayılarına ( $\beta$ ) göre, sosyal medya kullanımı alt boyutlarının davranışsal sadakat üzerindeki göreli önem sırası; "psikolojik motivasyon ve sosyal motivasyon" şeklindedir. T-testi sonuçları incelendiğinde ise psikolojik 
motivasyonun davranışsal sadakat üzerinde anlamlı bir etkisinin olduğu görülmektedir. $\mathrm{Bu}$ bulgular 1şı̆̆ında; $H_{2 e}$ hipotezi kabul edilmiştir.

Tablo 13 incelendiğinde "sosyal, psikolojik ve fonksiyonel motivasyon" ile "tutumsal sadakat" arasında yüksek ve orta düzeyde pozitif (sırasıyla; 0,$867 ; 0,510 ; 0,557$ ) ilişki olduğu anlaşılmaktadır. Bağımlı ve bağımsız değişkenler arasında orta düzeyde, anlamlı bir ilişki mevcuttur $\left(\mathrm{R}: 0,868, \mathrm{R}^{2}: 0,754, \mathrm{p}: 0,000\right)$. Standardize edilmiş regresyon katsayılarına $(\beta)$ göre, sosyal medya kullanımı alt boyutlarının tutumsal sadakat üzerindeki göreli önem sırası; "sosyal motivasyon, psikolojik motivasyon ve fonksiyonel motivasyon" şeklindedir. T-testi sonuçları incelendiğinde ise sosyal motivasyonun tutumsal sadakat üzerinde anlamlı bir etkisinin olduğu görülmektedir. Bu bulgular ışığında; $H_{2 j}$ hipotezi kabul edilmiştir.

Araştırma bulgularına göre kabul edilen ve reddedilen hipotezler aşağıdaki tablo-14'de gösterilmektedir.

Tablo 14: Hipotezlerin Kabul ve Ret Durumları

\begin{tabular}{|c|c|c|}
\hline $\begin{array}{l}\text { Hipotez } \\
\text { Kodları }\end{array}$ & Hipotezler & Kabul/Ret \\
\hline $\mathrm{H}_{1 \mathrm{a}, \mathrm{b}, \mathrm{c}}$ & $\begin{array}{l}\text { Sosyal medya kullanımı boyutlarından a)sosyal motivasyon, b)psikolojik } \\
\text { motivasyon, c)fonksiyonel motivasyon, Nike markasına göre marka } \\
\text { tanınırlığını etkilemektedir. }\end{array}$ & $\begin{array}{l}\text { a) Kabul } \\
\text { b) Ret } \\
\text { c) Ret }\end{array}$ \\
\hline $\mathrm{H}_{1 \mathrm{~d}, \mathrm{e}, \mathrm{f}}$ & $\begin{array}{l}\text { Sosyal medya kullanımı boyutlarından d)sosyal motivasyon, e)psikolojik } \\
\text { motivasyon, f)fonksiyonel motivasyon, Adidas markasına göre marka } \\
\text { tanınırlığını etkilemektedir. }\end{array}$ & $\begin{array}{l}\text { d) Ret } \\
\text { e) Kabul } \\
\text { f) Ret }\end{array}$ \\
\hline $\mathrm{H}_{1 \mathrm{~g}, \mathrm{~h}, \mathrm{i}}$ & $\begin{array}{l}\text { Sosyal medya kullanımı boyutlarından g)sosyal motivasyon, h)psikolojik } \\
\text { motivasyon, i)fonksiyonel motivasyon, Nike markasına göre marka } \\
\text { hatırlanırlığını etkilemektedir. }\end{array}$ & $\begin{array}{l}\text { g) Ret } \\
\text { h) Kabul } \\
\text { i) Ret }\end{array}$ \\
\hline $\mathrm{H}_{1 \mathrm{j}, \mathrm{k}, \mathrm{l}}$ & $\begin{array}{l}\text { Sosyal medya kullanımı boyutlarından j)sosyal motivasyon, k)psikolojik } \\
\text { motivasyon, 1)fonksiyonel motivasyon, Adidas markasına göre marka } \\
\text { hatırlanırlığını etkilemektedir. }\end{array}$ & $\begin{array}{l}\text { j) Kabul } \\
\text { k) Ret } \\
\text { 1) Ret }\end{array}$ \\
\hline $\mathrm{H}_{2 \mathrm{a}, \mathrm{b}, \mathrm{c}}$ & $\begin{array}{l}\text { Sosyal medya kullanımı boyutlarından a)sosyal motivasyon, b)psikolojik } \\
\text { motivasyon, c)fonksiyonel motivasyon Nike markasına göre davranışsal } \\
\text { sadakat algısını etkilemektedir. }\end{array}$ & $\begin{array}{l}\text { a) Kabul } \\
\text { b) Ret } \\
\text { c) Ret }\end{array}$ \\
\hline $\mathrm{H}_{2 \mathrm{~d}, \mathrm{e}, \mathrm{f}}$ & $\begin{array}{l}\text { Sosyal medya kullanımı boyutlarından d)sosyal motivasyon, e)psikolojik } \\
\text { motivasyon, f)fonksiyonel motivasyon Adidas markasına göre davranışsal } \\
\text { sadakat algısını etkilemektedir. }\end{array}$ & $\begin{array}{l}\text { d) Ret } \\
\text { e) Kabul } \\
\text { f) Ret }\end{array}$ \\
\hline $\mathrm{H}_{2 \mathrm{~g}, \mathrm{~h}, \mathrm{i}}$ & $\begin{array}{l}\text { Sosyal medya kullanımı boyutlarından g)sosyal motivasyon, h)psikolojik } \\
\text { motivasyon, i)fonksiyonel motivasyon Nike markasına göre tutumsal } \\
\text { sadakat algısını etkilemektedir. }\end{array}$ & $\begin{array}{l}\text { g) Ret } \\
\text { h) Kabul } \\
\text { i) Ret }\end{array}$ \\
\hline $\mathrm{H}_{2 \mathrm{j}, \mathrm{k}, \mathrm{l}}$ & $\begin{array}{l}\text { Sosyal medya kullanımı boyutlarından j)sosyal motivasyon, k)psikolojik } \\
\text { motivasyon, l)fonksiyonel motivasyon Adidas markasına göre tutumsal } \\
\text { sadakat algısını etkilemektedir. }\end{array}$ & $\begin{array}{l}\text { j) Kabul } \\
\text { k) Ret } \\
\text { 1) Ret }\end{array}$ \\
\hline
\end{tabular}

\section{Sonuç}

$\mathrm{Bu}$ çalışmada Adidas ve Nike markaları dikkate alınarak tüketicilerin sosyal medya kullanımı algısı ile birlikte marka farkındalığı ve marka sadakati arasındaki ilişki incelenmiştir. Bu doğrultuda anket tekniği ile toplanan verilere faktör analizi uygulanmıştır. Açımlayıcı faktör analizi sonuçlarına göre sosyal medya kullanımı algısına yönelik üç faktör ortaya çıkmıştır. Bu faktörler sosyal motivasyon, psikolojik motivasyon ve fonksiyonel motivasyondur. $\mathrm{Bu}$ sonuç ile Topal ve Temizkan'ın (2016) ve Ercan'ın (2016) yaptığı çalışma sonuçları benzerlik göstermektedir.

Marka farkındalığı açımlayıcı faktör analizi sonuçlarına göre ise iki faktör ortaya çıkmıştır. Bu faktörler marka tanınırlı̆̆ı ve hatırlanırlığıdır. Bu bulgu ile Aaker'in (1996) çalışması benzerlik göstermektedir. Marka sadakatine yönelik yapılan açımlayıcı faktör analizi sonuçlarına göre ise iki 
faktör ortaya çıkmıştır. Bu faktörler tutumsal ve davranışsal sadakattir. Bu sonuç ile Vural ve diğ. (2016) ve Yıldı'ın (2014) çalışmaları benzerlik göstermektedir.

Yapılan korelasyon analizi sonuçlarına göre Adidas ve Nike markası karşılaştırıldığında Sosyal medya kullanımı-Marka farkındalığı ilişkisinde Nike markası için tanınırlık, Adidas markası için hatırlanırlığın ön plana çıktığı anlaşılmıştır. Sosyal medya kullanımı-Marka sadakati ilişkisinde ise Nike markası için davranışsal sadakatin, Adidas markası için tutumsal sadakatin ön plana çıktığı anlaşılmıştır. Yani Nike markası kullanıcılarında daha çok satın alma sürekliliğinin olduğu, Adidas markasında ise daha çok duygusal bağlılığın olduğu anlaşılmıştır. Bu sonuçlar değerlendirildiğinde satın alma bağlılı̆̆ında rakiplerin promosyon faaliyetleri yapması, alternatiflerin çıkması vb. durumlarda müşterilerin işletmeyi terkedebilme olasılıklarının olduğu düşünülmektedir. Duygusal bağl1lıkta ise müşterilerin işletmeyi ve ürünü kolay kolay terk etmeyeceği olasılığ düşünülmektedir. Bu durumda Adidas markasının Nike markasına göre daha avantajlı olduğu düşünülmektedir.

Regresyon analizi sonuçlarına bakıldığında her iki marka için sosyal motivasyonun ve psikolojik motivasyonun marka farkındalığı ve marka sadakati üzerinde etkili olduğu görülmektedir. Bu sonuç Topal ve Temizkan'ın (2016) yaptığı çalışması ile benzerlik göstermesine rağmen Ercan'ın (2016) çalışmasından farklıdır. Ercan'ın (2016) çalışmasında fonksiyonel faydanın sadakat üzerinde etkisi çıkmıştır. Bu çalışma da ise fonksiyonel faydanın herhangi bir etkisi ortaya çıkmamıştır. Nike markasında sosyal motivasyonun marka tanınırlığı ve davranışsal sadakati, psikolojik motivasyonun ise marka hatırlanırlığ 1 ve tutumsal sadakati etkilediği görülmüştür. Adidas markasında sosyal motivasyonun marka hatırlanırlığı ve tutumsal sadakati, psikolojik motivasyonun ise marka tanınırlığı ve davranışsal sadakati etkilediği görülmüş̧ür. Fakat her iki markada da psikolojik motivasyonun etkisi anlamlı olmasına rağmen $\mathrm{R}^{2}$ değerlerinin düşük çıkması ilişkinin düşük olduğunu göstermektedir. Yani sosyal motivasyonun farkındalık ve sadakat ile her iki markada daha yüksek ilişki düzeyi olduğu anlaşılmıştır.

Betimleyici istatistik sonuçlarına bakıldığında sosyal medyanın kullanım amacının en fazla arkadaşlık ve eğlence olduğu görülmektedir. Alış-veriş ve modanın ise daha sonra geldiği görülmektedir. Araştırmanın örneklemi genel olarak düşünüldüğünde sosyal medyanın eğlence, arkadaşlık ve alış-veriş amaçlı kullandığı görülmektedir. En fazla kullanılan sosyal medya araçları ise sirasiyla YouTube, Facebook ve Instagramdir. Ayrica sosyal medya da 1 saat ile 4 saat arasinda en fazla zaman geçirildiği görülmüştür. Bu sonuçla Vural ve arkadaşlarının (2016), İşlek'in (2012), Topal ve Temizkan'ın (2016) çalışmaları ile We are Social araştırma şirketinin çalışmaları benzerlik göstermektedir.

Çalışma sonuçlarına göre sosyal medyanın hem marka tanınırlığı hem de marka hatırlanırlığı ile ilişkili olduğu anlaşılmaktadır. Spor giyim işletmelerine müşteri sadakati oluşturma ve marka farkındalığını arttırma konusunda aşağıda birtakım öneriler tavsiye edilebilir:

$\checkmark \quad$ marka farkındalığını arttırmak için etkileşimli, güncel ve güvenilir sanal ortamlar hazırlanabilir,

$\checkmark \quad$ araştırma sonuçlarına göre spor giyim tüketicilerine yönelik Youtube, Instagram ve Facebook sosyal medya araçları daha aktif kullanılabilir,

$\checkmark \quad$ müssteri sadakati sağlamada ve marka farkındalığı oluşturmada spor giyimle ilgili daha çok sosyal güdülerle ilgili mesajlar verilebilir,

$\checkmark \quad$ sosyal güdüler ile ilgili mesajları daha etkili hale getirebilmek için sosyal medyada marka toplulukları oluşturulabilir veya sanal topluluklara girilebilir.

$\mathrm{Bu}$ çalışmanın temel sınırlılığı spor giyim markalarından sadece Adidas ve Nike markasının dikkate alınmasıdır. Çalışma alanı diğer spor giyim markaları dikkate alınarak genişletilebilir. Öte yandan bu çalışma Düzce ili ile sınırlıdır. Ulusal, uluslararası veya bölgesel çapta çalışmalar 
yapılabilir. Spor giyim markalarının sosyal medyada yer alan içerikleri, kampanyaları, dikkate alınarak farklı çalışmalar yapılabilir. İşletmelerin sosyal medya çalışmaları ile tüketici-marka ilişsi kalitesi araştırılabilir.

\section{Kaynakça}

Aaker, D. A., (1996). Güçlü markalar yaratmak. E., Demir, Çev. İstanbul, MediaCat Kitapları, 2012.

Aktuğlu, I. K. (2014). Marka Yönetimi: Güçlü ve Başarılı Markalar İçin Temel İlkeler. 5. Baskı, İstanbul: İletişim Yayınları.

Altunışık, R., Çoşkun R., Bayraktaroğlu S. ve Yıldırım E. (2010). Sosyal bilimlerde araştırma yöntemleri SPSS uygulamalı. 6. Basım. Sakarya: Sakarya Yayıncılık.

Balakrishnan, B. K., Dahnil, M. I., \& Yi, W. J. (2014). The impact of social media marketing medium toward purchase intention and brand loyalty among generation Y. Procedia-Social and Behavioral Sciences, 148, 177-185. https://doi.org/10.1016/j.sbspro.2014.07.032

Barreda, A. A., Bilgihan, A., Nusair, K., \& Okumus, F. (2015). Generating brand awareness in online social networks. Computers in human behavior, 50, 600-609. http://dx.doi.org/10.1016/j.chb.2015.03.023

Büyüköztürk, Ş. (2015). Sosyal bilimler için veri analizi el kitabı. 21. Baskı. Ankara: Pegem Yayınları.

Çakırkaya, M., ve Koçyiğit, M. (2019). Sosyal medya iletişimi ve tüketici temelli marka değeri arasındaki ilişkinin incelenmesi: bir gsm markası üzerine tüketici araştırması. İşletme Araştırmaları Dergisi, 11(3), 2027-2039. https://doi.org/10.20491/isarder.2019.722

Çatı K., ve Koçoğlu, C. M. (2008). Müşteri sadakati ile müşteri tatmini arasındaki ilişkiyi belirlemeye yönelik bir araştırma. Selçuk Üniversitesi Sosyal Bilimler Enstitüsü Dergisi, (19), 167-188.

Çizmeci, F., \& Ercan, T. (2015). Konut firmalarının marka farkındalığı yaratmak amacıyla kullandıkları dijital pazarlama iletişimi araçlarının etki seviyelerinin değerlendirilmesi. MEGARON/Yıldız Teknik Üniversitesi, Mimarlık Fakültesi EDergisi, 10(2), 149-161. https://doi.org/10.5505/megaron.2015.73745

Daugherty, T., Eastin, M. S., \& Bright, L. (2008). Exploring consumer motivations for creating usergenerated content. Journal of interactive advertising, 8(2), 16-25. https://doi.org/10.1080/15252019.2008.10722139

Dick, A. \& Basu, K. (1994). Customer loyalty: toward an integrated conceptual framework. Journal of the Academy of Marketing Science 22(2), 99-113.

Dilmen, N. (2007). Yeni medya kavramı çerçevesinde internet günlükleri-bloglar ve gazeteciliğe yansımaları. Marmara İletişim Dergisi, 12(12), 113-122. https://doi.org/10.1177/0092070394222001

Ercan, F. (2016). Otel işletmelerinde sosyal medyanın müşteri e-sadakati üzerine etkisi: Facebook örneği. Yüksek lisans tezi, Adnan Menderes Üniversitesi Sosyal Bilimler Enstitüsü, Turizm Işletmeciliği Anabilim Dall. https://doi.org/10.17719/jisr.2017.1532

Erdoğmuş, İ. E., ve Cicek, M. (2012). The impact of social media marketing on brand loyalty. Procedia-Social and Behavioral Sciences, 58, 1353-1360. https://doi.org/10.1016/j.sbspro.2012.09.1119 
Eren, S. S. ve Erge, A. (2012). Marka güveni, marka memnuniyeti ve müşteri değerinin tüketicilerin marka sadakati üzerine etkisi. Journal of Yaşar University, 26(7), 4455 - 4482.

Gümüş, N., ve Zengin, H. (2018). Sosyal medya kavramı ve tarihsel gelişimi. Niyazi Gümüş (ed.) KOBI'ler için sosyal medya içinden (s 1-40). Akademisyen Yayınevi, Ankara.

Gümüş, N., Zengin, H., \& Geçti, F. (2013). Sosyal medya aracı olarak facebook uygulamalarının marka denkliği üzerindeki etkisi: bir gsm operatörünün facebook sayfası üzerinde araştırma. Sakarya İktisat Dergisi, 2(2), 87-117.

Hutter, K., Hautz, J., Dennhardt, S., \& Füller, J. (2013). The impact of user interactions in social media on brand awareness and purchase intention: the case of MINI on Facebook. Journal of Product \& Brand Management. https://doi.org/10.1108/JPBM-05-2013-0299

Iovino, P. (2011). An estimation of the technology acceptance model and usage intensity on online social networks: the LUISS students case. Access link: http://tesi.luiss.it/6080/1/iovino-tesi2011.pdf

İşlek, M. S., (2012). Sosyal medyanın tüketici davranışlarına etkileri: Türkiye'deki sosyal medya kullanıcıları üzerine bir araştırma. Yüksek lisans tezi, Karamanoğlu Mehmet Bey Üniversitesi.

Karagöz, Y. ve Kösterelioğlu İ. (2008). İletişim becerileri değerlendirme ölçeğinin faktör analizi metodu ile geliştirilmesi. Dumlupınar Üniversitesi Sosyal Bilimler Dergisi, 21, 81-97.

Karakuş, O., (2015). Beşiktaş, Fenerbahçe ve Galatasaray spor kulüplerinin sosyal medya aracıllğı ile taraftarları üzerinde marka sadakati oluşturma çalışmalarının değerlendirilmesi. Yüksek lisans tezi, Marmara Üniversitesi.

Kaynar, O., Tuna, M. F., Görmez, Y., \& Deveci, M. A. (2017). Makine öğrenmesi yöntemleriyle müşteri kaybı analizi. Cumhuriyet Üniversitesi İktisadi ve İdari Bilimler Dergisi, 18(1), 114.

Kazanc1, Ş., \& Başgöze, P. (2015). Sosyal medya algısının, marka kredibilitesinin ve marka prestijinin satın alma eğilimi üzerine etkileri. Ankara Üniversitesi Sbf Dergisi, 70(2), 435456.

Keller, K. L. (2013). Strategic brand management. 4th Edition, Pearson Education.

Kim, K. J., Jeong, I. J., Park, J. C., Park, Y. J., Kim, C. G., \& Kim, T. H. (2007). The impact of network service performance on customer satisfaction and loyalty: High-speed internet service case in Korea. Expert Systems with Applications, 32(3), 822-831. https://doi.org/10.1016/j.eswa.2006.01.022

Laroche, M., Habibi, M. R., \& Richard, M. O. (2013). To be or not to be in social media: How brand loyalty is affected by social media? International Journal of Information Management, 33(1), 76-82. https://doi.org/10.1016/j.ijinfomgt.2012.07.003

Lau, G. T. \& Lee, S. H. (1999). Consumers' trust in a brand and the link to brand loyalty. Journal of Market Focused Management, 4, 341-370.

Murugesan, S. (2007). Understanding Web 2.0. IT professional, 9(4), 34-41. https://doi.org/10.1109/MITP.2007.78

Richter, F. (2018) The Most Visible Brands on Social Media. Erişim Linki: https://www.statista.com/chart/12693/brands-most-often-featured-in-instagram-and-twitterphotos/ Erişim tarihi: 22.10.2019 
Schivinski, B. \& Dabrowski, D. (2016). The effect of social media communication on consumer perceptions of brands. Journal of Marketing Communications, 22(2), 189-214. https://doi.org/10.1080/13527266.2013.871323

Tatar, Ş. B., \& Eren-Erdoğmuş, İ. (2016). The effect of social media marketing on brand trust and brand loyalty for hotels. Information Technology \& Tourism, 16(3), 249-263. https://doi.org/10.1007/s40558-015-0048-6

Topal, İ., \& Temizkan, V. (2016). Tüketicilerin mobil sosyal medya kullanımının marka farkındalığına etkisi. Insan ve Toplum Bilimleri Araştırmaları Dergisi, 5(5), 1456-1473.

Tosun, N. B. (2014). Marka yönetimi. Beta Basım Yayım Dağıtım, İstanbul.

TÜİK, (2017). Hanehalkı Bilişim Teknolojileri Kullanım Araştırması. Erişim Linki: http://www.tuik.gov.tr/HbPrint.do?id=24862

Vural, Z., \& Bat, M. (2010). Yeni bir iletişim ortamı olarak sosyal medya: ege üniversitesi iletişim fakültesine yönelik bir araştırma. Journal of Yasar University, 5(20).

Vural. A. Z. B., Dincer, K. M., Başok, N., Değirmen, G. Ç, Yalçın, M., \& Erkan, M. (2016). Marka farkındalığında sosyal medya kullanımı: karşılaştırmalı bir analiz. Journal of International Social Research, 9(45) 663-674. https://doi.org/10.17719/jisr.20164520645

Wearesocial, (2019). The State Of Digital In April 2019: All The Numbers You Need To Know. Erişim linki: https://wearesocial.com/blog/2019/04/the-state-of-digital-in-april-2019-allthe-numbers-you-need-to-know Erişim tarihi: 05.02.2020

Wearesocial, (2017). Digital In 2017: Global Overvıew. Erişim linki: https://wearesocial.com/special-reports Erişim tarihi: 10.10.2019

Yıldırım, F., ve Boztepe, A. (2019). Bireylerin moda satın alma davranışı ve sosyal medya kullanımı ilişkisi üzerine bir araştırma. İstanbul Ticaret Üniversitesi Sosyal Bilimler Dergisi, 18(35), 325-349.

Yıldız, Y. (2014). Tüketici davranışları üzerinde sosyal medya etkileri: Apple ve Samsung örneği. Kastamonu Üniversitesi İktisadi ve İdari Bilimler Fakültesi Dergisi, 4(2), 5-15.

Zeithaml, V.A., Berry, L.L., Parasuraman, A., (1996). The behavioral consequences of service quality. Journal of Marketing, 60 (2), 31-46. https://doi.org/10.2307/1251929 